\title{
Tragom Rikarda Vikerta, posljednjega međuratnog upravitelja zagrebačke policije
}

\author{
MARIO STIPANČEVIĆ \\ Hrvatski državni arhiv \\ Zagreb, Hrvatska \\ mstipancevic@arhiv.hr
}

\begin{abstract}
Bivšega policijskog upravitelja u Banjoj Luci i Sarajevu vlastodršci su krajem 1940. odabrali za ravnatelja zagrebačkoga redarstvenog ravnateljstva kao zamjenu za nepouzdanoga Josipa Vragovića. Svojim je iskustvom i oštrim pristupom prema neistomišljenicima političkoga poretka, prokušanim tijekom sedamnaestogodišnje policijske službe, trebao suspregnuti sve snažniju djelatnost komunističkih i ustaško-frankovačkih snaga u hrvatskoj metropoli neposredno pred početak ratnih operacija na ovim prostorima. U prilogu se nastoji približiti Vikertov profesionalni i privatni život uz iznošenje podataka o njegovoj povezanosti s onodobnim političkim strukturama, načinu ophođenja s protivnicima režima te najbližim suradnicima. Posebna je pozornost posvećena upravljanju policijom u Banjoj Luci, Sarajevu i Zagrebu, što je naposljetku i dovelo do toga da je samo nekoliko dana nakon uspostave Nezavisne Države Hrvatske postao jednom od za režim najnepoželjnijih osoba.
\end{abstract}

Ključne riječi: Rikard Vikert; biografija; redarstvo; Kraljevina Srba, Hrvata i Slovenaca / Jugoslavija; Nezavisna Država Hrvatska

\section{Ususret nepoznatome}

Za Hrvate tegobne prilike unutar onodobne jugoslavenske državne zajednice, poznato je, trebale su barem donekle biti razriješene uspostavom Banovine Hrvatske. Međutim tobožnje napuštanje centralističkoga koncepta upravljanja i davanje šire autonomije Hrvatskoj beogradskih vladajućih krugova vrlo se brzo pokazalo neiskrenim i nasilu iznuđenim, pa se u stvarnom životu pripadnika hrvatskoga društva malošto uistinu korjenito promijenilo. Spomenuto je, među ostalim, potvrdila i smjena dotadašnjega ravnatelja zagrebačke policije Josipa Vragovića u osvit Drugoga svjetskog rata, kao jedan od posljednjih, očajničkih poteza umiruće monarhije u pokušaju obuzdavanja njezina unutarnjega rasapa. U hrvatskoj su prijestolnici pored komunista naime još i veća prijetnja tomu bili pripadnici ilegalnoga i emigrantskoga ustaškog pokreta. Prema mišljenju onodobnoga beogradskog režima, temeljenom na obavještajnim izvorima, Vragović se u drugome mandatu na čelu redarstva 
prema ustašama pokazao ne samo popustljivim nego ih je i otvoreno štitio. Da su takvi stavovi doista mogli biti utemeljeni u stvarnosti, svjedoči njegov kasniji profesionalni napredak unutar redarstvenoga aparata Nezavisne Države Hrvatske (NDH).

Da bi se stanje u zagrebačkom redarstvu za vladajuće barem donekle popravilo, a centralistički obrasci vladanja ostali na manje rasklimanim temeljima, na Vragovićevo je mjesto potkraj 1940. postavljen Rikard (Rihard, Rikardo) Vikert (Wikkert, Wikert, Wickert, Vickert), bivši policijski ravnatelj iz Banje Luke i Sarajeva, režimski pouzdanik koji je trebao spriječiti dodatno rasplamsavanje protudržavnoga djelovanja u hrvatskoj prijestolnici. Od svih međuratnih upravitelja zagrebačkoga redarstva Vikert je ponajmanje poznat (historiografskoj) javnosti. O njemu svjedoči tek nekoliko razbacanih navoda iz tiska i literature, iz kojih se uz ostalo može iščitati da je zbog prijašnjega policijskog djelovanja odmah po uspostavi NDH postao jednim od najtraženijih državnih neprijatelja novoustrojenoga ustaškog režima. I to je uglavnom sve jer, baš kao što je rijetko spominjan u tiskovinama, razmjerno su rijetka i izvorna arhivska vrela koja ga spominju.

Primjena deskriptivne metode pri razlaganju životopisa dobar je način detaljnijega prikazivanja prošle stvarnosti, koji međutim nosi i skrivene zamke poput pretjeranoga opisivanja naoko nevažnih detalja radi potpunijega iskorištavanja informacija iz rijetkih raspoloživih izvora, što na kraju umnogome može opteretiti tekst ili zamagliti najvažnije događaje. U nadi da se to nije dogodilo, prilog koji čitatelj ima pred sobom nastoji približiti obrise intrigantne i nedovoljno razjašnjene biografije posljednjega međuratnoga zagrebačkoga redarstvenog ravnatelja. Usprkos mikrohistorijskoj uokvirenosti, on bi trebao pripomoći boljem razumijevanju promatranoga razdoblja kao i događaja koji su posljedično obilježili možda i najtraumatičniji odlomak XX. stoljeća. Imajući pritom u vidu da prikazano neizbježno odstupa od stvarnih događaja te da je istina o prošloj stvarnosti rijetko posve dostupna.

\section{Krivotvorine života}

Vikert je rođen 27. veljače 1889. u Vinkovcima od oca Adolfa ( ${ }^{\star} 1863$.) i majke Ivane rođ. Krema ( ${ }^{\star} 1864$.). Prema dostupnim podacima, imao je i četiri godine mlađu sestru Sofiju Zoricu ( ${ }^{\star} 1893$.), a obitelj je bila zavičajna u spomenutom srijemskom gradu. ${ }^{2}$ Otac Adolf bio je sin Matije iz obližnjih Starih Mikanovaca, a majka Ivana, kći Franje i Georgine rođ. Andrić, rođena je u Vinkovcima. Vjenčali su se u studenome 1883. u vinkovačkoj župnoj crkvi i

\footnotetext{
1 STIPANČEVIĆ, „Stranputice Joje Vragovića”, 117-120.

2 HR-DAVU-VK-124-UOV, Imenik zavičajnika 1909., knj. 4; HR-HDA-1448-ZBMK, ZM34C/103, župa Vinkovci, MKR 1880.-1903.
} 
prebivali na kućnom broju 50. ${ }^{3}$ Prilikom Rikardova rođenja Adolf je zabilježen kao porezni činovnik, ${ }^{4}$ a izvori ga poslije spominju kao posjednika. ${ }^{5}$

U Rikardovu je službeničkom listu iz travnja 1930. zabilježeno da je iska-

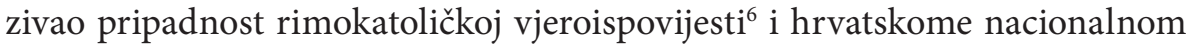
korpusu. Kraj oba je navoda nakon uspostave NDH crvenom olovkom naznačen upitnik. ${ }^{7}$ Nije teško dokučiti zašto. Ustaškoj se administraciji činilo nemogućim da se osoba njegova životnoga opusa mogla smatrati katolikom i Hrvatom. Za službenu politiku i javnost novostvorene države Vikert je osobno falsificirao službenički list, namjerno ga krajem 1940. antedatirajući u 1930., pritom iskrivljeno navodeći spomenute podatke o vjeroispovijesti i nacionalnoj pripadnosti „Znajući kakav će revolt izazvati njegovo postavljanje za ravnatelja redar[s]tva u Zagrebu kao poznatog hrvatoždera i pokrštenog pravoslavca”. ${ }^{8}$ Prema istim navodima, Vikert se do samoga dolaska u Zagreb u službenim dokumentima držao pripadnikom „srpsko-hrvatske” nacionalnosti i pravoslavne vjeroispovijesti, što su navodno mogli potvrditi neki bivši viši činovnici banske uprave u Sarajevu poput dr. Bogdana Stefanovića, ${ }^{9} \mathrm{Mi}$ lutina Popovića, dr. Melka Gozze ${ }^{10}$ i dr. Ivana Topalija, ${ }^{11}$ koji su njegov izvorni činovnički list svojevremeno imali u rukama. ${ }^{12}$

Je li doista bilo tako, gotovo je nemoguće sa sigurnošću utvrditi. Ono što se može reći na temelju spornoga, do danas sačuvanoga činovničkog lista jest da su svi upisi do uključujući za 1939. pisani istom rukom i istom olovkom, a da su oni za 1940. i 1941. naznačeni naknadno različitim rukopisima i pisaljkama. ${ }^{13}$ To svakako svjedoči u prilog tvrdnji onodobne endehazijske administracije o naknadnom prijepisu i antedatiranju dokumenta. Osim spome-

\begin{aligned} \hline 3 & HR-HDA-1448-ZBMK, ZM-34C/104, župa Vinkovci, MKV 1879.-1915. \\ 4 & HR-HDA-1448-ZBMK, ZM-34C/103, župa Vinkovci, MKR 1880.-1903. \\ 5 & HR-DAVU-VK-124-UOV, Imenik zavičajnika 1909., knj. 4. \\ 6 & Nedvojbeno je rođen i kršten u rimokatoličkoj vjeroispovijesti budući da pored matice \end{aligned} rođenih o tome svjedoči i upis u školsku maticu vinkovačke Oberschule (HR-DAVU-VK-38OŠ JK, Glavni imenik /matica/ 1890.-1904., knj. 10).

7 HR-HDA-223-MUP NDH, inv. br. 1768.

8 „Zloglasni Rikard Vikert”, Hrvatski narod (Zagreb), 22. 4. 1941., 8.

9 Stefanović je umirovljen u veljači 1942. u svojstvu „odjelnoga savjetnika V. činovničkog razreda kod zapovjedništva vojne krajine u Sarajevu". Budući da je na administrativnim poslovima bio zaposlen od 1912., u vrijeme umirovljenja iza sebe je imao punih trideset godina radnoga staža. Službu je napustio zbog narušenoga zdravstvenog stanja. Na kraju profesionalne karijere živio je u Sarajevu kao udovac bez djece (HR-HDA-223-MUP NDH, inv. br. 1215).

10 Melko Gozze-Gučetić umirovljen je kao odjelni savjetnik III. položajne grupe kod „povjereništva Nezavisne države Hrvatske u Sarajevu” u rujnu 1941. nakon 29 godina službe (HRHDA-223-MUP NDH, inv. br. 1862).

11 Policijski komesar Ivan Topali zabilježen je sredinom 1937. kao Vikertov zamjenik u vrijeme njegove odsutnosti radi davanja ,šestonedeljnog Parastosa u Zemunu [...] umrloj tašti”. Nije naodmet primijetiti da je Vikert molbu za dopust u kojoj je Topalija imenovao zamjenikom potpisao ćirilicom, kojom je pisan i cijeli dokument (HR-HDA-223-MUP NDH, inv. br. 1768).

12 „Zloglasni Rikard Vikert”, Hrvatski narod, 22. 4. 1941., 8.

13 HR-HDA-223-MUP NDH, inv. br. 1768. 
nutoga, na temelju nekoliko raspoloživih Vikertovih potpisa, posebice onoga na predmetnom službeničkom listu, moglo bi se s oprezom potvrditi da su svi zapisi o profesionalnom životu do 1939. doista bili bilježeni Vikertovom rukom i istovremeno. To, čini se, nije bilo slučajno, pa je i vjerojatnost da su podaci u njemu naknadno promijenjeni u odnosu na prethodne službene dokumente prilično izvjesna.

O tome posredno svjedoči i podatak o Vikertovu bračnom statusu. Naime, u službeničkom je listu zabilježeno da je od 19. lipnja 1919. bio oženjen Mirom rođ. Nikolić, a kao dokazi su navedeni „Vjenčani list Srp. Prav. Paroh. [...] Zemun” i „Vjenčani list Rimokatol. Žup. Ureda Krista Kralja u Beogradu”. ${ }^{14}$ Navod je sam po sebi proturječan, što je moralo biti jasno i suvremenicima, jer su se vjenčanja tada, kao i danas, u ovakvim slučajevima mogla obavljati isključivo u jednoj od vjeroispovijesti za koju su se mladenci odlučili, a nikako u obje istovremeno. Vjerojatno je Vikert nenavođenjem datuma drugoga vjenčanja pokušavao zamesti „kompromitirajuće” tragove, što na kraju nije uspio. U Hrvatskoj su bili dobro upoznati (i) s njegovom privatnom prošlošću. Tako je u već spomenutim tiskovnim navodima zabilježeno da se „[v]rativši [...] iz srpske vojske 1919. g. oženio [...] s kćeri zemunskog prote”, ${ }^{15}$ a ako je Vikertova supruga doista bila kći pravoslavnoga parohijalnog svećenika, ne treba čuditi da se s njom vjenčao po istočnom (pravoslavnom) obredu. Ovu priču dodatno potkrepljuje podatak zabilježen uz Vikertovo ime u matici rođenih, prema kojem je „Vjenčan dne 3. VII. 1937. u Beogradu (konvalidacija) sa Mirjanom Nikolić (ist. prav.)". 16 To je naposljetku i potvrđeno uvidom u matice vjenčanih beogradske katoličke župe Krista Kralja, u kojima je zabilježeno da su Vikert i Mirjana Nikolić (kći Pavla Nikolića i Kristine Balko, rođena 1897. u Pančevu) kao „mladenci” sklopili brak 3. srpnja 1937. godine. Na vjenčanju su im kumovali kapelan Andrija Hrubiany i činovnik Ferdinand Zajac. Petnaestak dana prije vjenčanja rješenjem Nadbiskupskoga ordinarijata u Beogradu od 18. lipnja 1937. paru je „podeljen oprost od meš. [ovite] veze”, ${ }^{17}$ čime je, očito, za Katoličku crkvu raniji pravoslavni brak postao ništavnim.

Što je nagnalo Vikerta da se punih osamnaest godina nakon ženidbe u pravoslavnoj crkvi ponovno vjenča s istom osobom u katoličkoj, nezahvalno je i pretpostavljati. Možda se znatno prije povratka u Hrvatsku i Zagreb počeo pripremati za takvu mogućnost, a možda su razlozi bili mnogo običniji (ali time ne i manje nedokučivi). Znakovito je međutim da je na vjenčanju kao jedan od svjedoka upisan kapelan Andrija Hrubiany (Hrubiány Endre), tada mladi svećenik, rođen 1910. u bačkim Odžacima (Hódság), koji je samo jednu godinu - i to baš 1937. - obnašao dužnost kapelana u Beogradu, a zatim

14 Isto.

15 „Zloglasni Rikard Vikert”, Hrvatski narod, 22. 4. 1941., 8.

16 HR-HDA-1448-ZBMK, ZM-34C/103, župa Vinkovci, MKR 1880.-1903.

17 Podaci iz matice vjenčanih dobiveni su 26. svibnja 2020. susretljivošću don Aleksandra Kovačevića, župnika župe Krista Kralja u Beogradu i generalnoga vikara Beogradske nadbiskupije. 
nastavio sa svećeništvom u Mađarskoj. ${ }^{18}$ Prema dostupnim Hrubianyijevim biografskim podacima, supružnici su ga prije samoga čina vjenčanja teško mogli i bolje poznavati, a kamoli smatrati prijateljem. Mnogo je vjerojatnije da se Vikert na katoličko vjenčanje odlučio žurno i bez znanja osoba iz svoje bliže okoline. Inače bi valjda za svjedoka pozvao sebi ili supruzi bliskiju osobu od kapelana crkve u kojoj se odvijao obred.

\section{Diplomirani apsolvent}

Zasad je nepoznato gdje je i u koje doba priveo kraju pučku školu. Prva je znanja počeo stjecati u vinkovačkoj Oberschule, u kojoj su se obrazovala gradska te djeca iz neposredne vinkovačke okolice. Međutim, iste godine u kojoj je započeo školovanje - 1896. - tu je ustanovu i napustio, kako se čini, zbog odlaska u Bosnu. ${ }^{19}$ Pobliži podaci o daljnjemu neposrednom slijedu događaja i obrazovanja, nažalost, ne mogu se ni nazreti. Nakon završetka pučke škole, kako i priliči potomku žitelja ne tako davno dokinute Vojne granice, školovanje je nastavio u Pješačkoj kadetskoj školi u Karlovcu (K.u.k. Infanterie-Kadettenschule in Karlstadt), ${ }^{20}$ koju završava 1909. godine. ${ }^{21} \mathrm{Ni}$ potonji navod nije za endehazijski tisak ostao bez sumnje. Prema njegovim podacima, Vikert je karlovačku kadetsku školu samo apsolvirao, pa je zbog toga 1923. polagao ispit zrelosti u Zemunu, pri čemu je dobio potvrdu (ne i svjedodžbu) sljedećega sadržaja:

„Kr. realna gimnazija u Zemunu 839-66-1923. Ovim se potvrđuje da je RIKARD VIKERT rodom iz Vinkovaca, istočno pravoslavne vjere položio ispit zrelosti te prema tomu može pohadjati sveučilište. Ova se potvrda izdaje mjesto svjedodžbe, jer nema propisanih tiskanica. Zemun 28. IX. 1923."22

Prema raspoloživim podacima crpljenim iz arhivskih vrela, taj se navod može potvrditi. Doista je sačuvan ovjerovljeni prijepis „Uredovne potvrde” zemunske Realne gimnazije s identičnim sadržajem. ${ }^{23}$ Ono što međutim baca sumnju u autentičnost prijepisa jest činjenica da izvornik „Uredovne potvrde" zemunske Realne gimnazije pod spomenutim brojem u sačuvanom arhivskom gradivu nije pronađen niti je njezino postojanje potvrđeno u uredskim knjigama škole iz toga razdoblja. ${ }^{24}$

Mnogo je sigurnije da se neposredno pred početak Prvoga svjetskog rata Vikert kao časnik nalazio u djelatnoj vojnoj, odnosno oružničkoj službi u

\footnotetext{
18 „Hrubiány Endre”.

19 HR-DAVU-VK-38-OŠ JK, Glavni imenik (matica) 1890.-1904., knj. 10.

20 Više o školi u: MIRNIK, „Ljetopis Carske i kraljevske pješačke kadetske škole u Karlovcu”.

21 HR-HDA-223-MUP NDH, inv. br. 1768.

22 „Zloglasni Rikard Vikert”, Hrvatski narod, 22. 4. 1941., 8.

23 HR-HDA-223-MUP NDH, inv. br. 1768.

24 Zahvaljujem kolegama iz Istorijskoga arhiva Beograda na provjeri gradiva fonda $270-$ Prva zemunska gimnazija.
} 
okviru zagrebačkoga oružničkog zapovjedništva. U Zagrebu je u to vrijeme položio i propisani oružnički časnički ispit. ${ }^{25}$ Tijekom razmjerno mirnoga predratnog razdoblja imao je vremena baviti se i sportom. Ostalo je zabilježeno da se u organizaciji „Hrvatskoga akademskog športskog kluba” (HAŠK) od 10. do 14. veljače 1913. u Mrkoplju trebao održati „prvi ski tečaj”, za koji je, prema navodima onodobnoga tiska, vladalo veliko zanimanje u zagrebačkim i riječkim sportskim krugovima. „Tečaj je trebao voditi hrvatskim skijašima dobro poznati oružnički poručnik Rikard Vikert, koji je svojevremeno bio učenikom Norvežanina Wibourg Tjuna." ${ }^{26}$ Prema dostupnim podacima, doista je u tom goranskome mjestu „[a]ustrijski poručnik Rikard Vickert [...] u veljači 1913. održao skijaški tečaj za četrnaest polaznika”, nakon kojega je $\mathrm{s}$ istaknutim hrvatskim sportašima Antom Pandakovićem i Ivom Lipovšćakom poduzeo i prvi zimski planinarski uspon na skijama na vrh Bjelolasice. ${ }^{27}$

Prema prethodnim se navodima može pretpostaviti da je Vikert bio član skijaške sekcije HAŠK-a, osnovane 1909., u čije je ime i vodio skijaški tečaj četiri godine poslije, a koji se smatra prvim u nas. Ta sekcija HAŠK-a početkom 1914. u Mrkoplju je održala i drugi skijaški tečaj, nakon kojega je održano i prvo skijaško prvenstvo Hrvatske i Slavonije na stazi dugoj $7 \mathrm{~km} .{ }^{28} \mathrm{Nema}$ podataka da je na njemu sudjelovao i Vikert.

Po završetku Prvoga svjetskog rata, u kojemu je, kako će se vidjeti, na vrijeme odabrao „pravu” stranu, kao i navodno položenom ispitu zrelosti u zemunskoj gimnaziji krajem 1923., bila su mu širom otvorena vrata i akademske naobrazbe. Upisao je studij na Pravnom fakultetu u Beogradu i, prema službenim podacima, „diplomirao” 1927. godine. ${ }^{29}$ No tisak je nakon uspostave $\mathrm{NDH}$ i te podatke tumačio drukčije. Prema tim je navodima Vikert fakultet samo „navodno” završio, o čemu je posjedovao „potvrdu”, ne i „pojedinačnu svjedodžbu" kakvu su morali podastrijeti svi pravnici prije stupanja u državnu službu. Ta potvrda o završenom fakultetu, prema istim navodima, nije bila istovjetna s diplomom beogradskoga Pravnog fakulteta. ${ }^{30}$

Nije nemoguće da su tiskovni navodi i u vezi s tim bili bliski istini jer u raspoloživim službenim dokumentima (na koje su se autori novinskih priloga, među ostalim, najvjerojatnije i oslanjali) Vikert doista nije iznio uvjerljive podatke o završetku studija prava. Umjesto preciznih informacija o diplomi, kao dokaz akademske obrazovanosti naveo je „Uverenje Prav. fak. 2332/27.”, ${ }^{31}$

\footnotetext{
25 HR-HDA-223-MUP NDH, inv. br. 1768.

26 „Ski-Tečaj”, Jutarnji list (Zagreb), 7. 2. 1913., 4. Potonji bi možda mogao biti svestrani norveški sportaš i proizvođač skijaške opreme Rolf Wiborg Thune (1883. - 1984.), koji je početkom XX. stoljeća bio poznat po uspješnom promicanju zimskih sportova. Usp. „Rolf Wiborg Thune” (1); „Norwegian ski manufacturers”; „Rolf Wiborg Thune” (2).

27 JAJČEVIĆ, 100 godina skijanja u Zagrebu, 19.

28 Isto.

29 HR-HDA-223-MUP NDH, inv. br. 1768.

30 „Zloglasni Rikard Vikert”, Hrvatski narod, 22. 4. 1941., 8.

31 U Službenom listu doslovno je navedeno sljedeće: „Diploma Prav. fakulteta Beogr. Univerziteta /: Uverenje Prav. fak. 2332/27.” Posve je jasno zbog čega jer je, nasreću, i samo „Uve-
} 
što svakako ostavlja mjesta sumnji o potpunom dovršetku fakultetske naobrazbe, ${ }^{32}$ kako je prosuđivao i endehazijski tisak. Usto, zbog tih nedoumica imao je poteškoća i u službi. Glavna je kontrola naime svojevremeno tužila Ministarstvo unutarnjih poslova Državnom savjetu zbog protupropisnoga prevođenja „sekretara Ministarstva Unutrašnjih Dela” Vikerta (7. srpnja 1927.) iz druge grupe II. kategorije u šestu grupu I. kategorije. Ministarstvo se od optužbi branilo činjenicom da im je Vikert krajem lipnja 1927. „podneo uverenje Pravničkog Fakulteta Univerziteta u Beogradu [...] da je položio sve ispite i stekao diplomu o svršenom Pravnom Fakultetu", na temelju čega je „preveden” u višu službeničku grupu i kategoriju te da za to nije bio potreban poseban ukaz kao u slučaju "postavljanja u jednoj od glavnih grupa”, ${ }^{33}$ što je Glavna kontrola očito držala propustom u poslovanju.

Bez obzira na to, za napredovanje u službi starojugoslavenske države sve mu to nije smetalo. Stare su zasluge očito mimoilazile propisana pravila koja su vrijedila za većinu ostalih službenika onodobnoga upravnog aparata.

\section{„Za vernost otadžbini”}

Već u prvim mjesecima Velikoga rata Vikert je naime promijenio stranu. U tome se slažu svi raspoloživi podaci. Službeni dokumenti svjedoče da je od 18. kolovoza 1909. do 20. listopada 1914. službovao u „austroug. vojsci i hrvatskoj žandarmeriji”, a od 20. listopada 1914. do 20. ožujka 1920. u „srpskoj vojsci”; 34 u tisku je nakon uspostave NDH zabilježeno da je „kao aktivni austrijski poručnik prebjegao [...] 1914. g. iz Zemuna srpskoj vojski kao dragovoljac u Beograd i kao takav prešao na pravoslavnu vjeru". ${ }^{35}$

I Vikert je osobno iznosio da je krajem listopada 1914. srpskoj vojsci pristupio kao „dobrovoljac borac”, usput spominjući i pripadajuće „uvjerenje Min. Voj. i Mornarice Adj. br. 12901 od 16/6. 1934.”, koje je to moglo potvrditi. ${ }^{36}$ Zbog čega se odlučio na dezertiranje, ostaje nepoznanicom. Prelasci austrougarskih časnika u protivničke redove u tako ranoj fazi ratnih djelovanja i bez prethodnoga zarobljavanja rijetko su dokumentirani, a kao kadeta i časnika austrougarske vojske teško ga možemo povezati i s idejama "revolucionarne omladine” koja je u predratnom razdoblju bila nositeljem protuhabsburških i prosrpskih

renje” sačuvano. U njemu, među ostalim, stoji: „Gospodin Rihard. A. Vikert, rodom iz Vinkovaca u Sremu, svršio je kao redovni učenik fakultet u Beogradu, položio je sve propisne ispite i stekao pravo na diplomu o svršenom pravnom fakultetu" (HR-HDA-223-MUP NDH, inv. br. 1768).

32 Zapošljavanje pojedinaca bez završenoga fakulteta na odgovorne pozicije u državnoj službi tada nije bilo rijedak slučaj, a najčešće se opravdavalo pomanjkanjem kvalificiranoga kadra. O tome više u: GRGIĆ, Između režimske ideologije i potreba građana, 248-249, 335.

33 HR-HDA-223-MUP NDH, inv. br. 1768.

34 Isto.

35 „Zloglasni Rikard Vikert”, Hrvatski narod, 22. 4. 1941., 8.

36 HR-HDA-223-MUP NDH, inv. br. 1768. 
političkih ideja u Hrvatskoj. ${ }^{37}$ Uostalom, i ta je omladina početak rata dočekala posve zdvojna, pa nije, kao ni drugi slojevi hrvatskoga društva, podignula glas protiv Monarhije. ${ }^{38}$ Suprotno tomu, čini se da je c. i kr. poručnik Vikert bio većim poklonikom ideje ujedinjenja od dijela onodobne mladeži koja se bespogovorno, pa i s oduševljenjem, priključila austrougarskom ratnom stroju u napadu na politički i državni ideal koji je sve donedavno obasipala lovorikama.

Prema dostupnim vrelima, posredno se može doznati da je sam početak rata dočekao u Zemunu i (Srijemskoj) Mitrovici kao oružnički poručnik. ${ }^{39}$ Budući da je služio u tom pomoćnom rodu vojske zaduženom za održavanje javnoga reda i sigurnosti, vjerojatno je morao biti dobro upoznat s raspoloženjem stanovništva i prilikama koje su vladale u tom pograničnom području pred početak izbijanja sukoba. Možda je skorom prelasku na protivničku stranu presudila i ljubav. Nije naodmet spomenuti da je dezertirao upravo u Zemunu, mjestu u kojem je pronašao životnu suputnicu Mirjanu, kćer vlasnice zemunskoga paromlina Kristine Nikolić, a vrlo su vjerojatno i majka i kći oduševljeno prihvatile kratkotrajni ulazak pripadnika srpske vojske u Zemun 10. rujna 1914. kao i velika većina tamošnjega stanovništva, koja ih je pozdravila kao osloboditelje. ${ }^{40}$

To je učinio i sam Vikert, čini se, već otprije dobro surađujući s tamošnjim srpskim stanovništvom. Naime, na samom početku rujna, još prije prodora srpskih snaga iz Beograda, zabilježeno je da je „austriski žandar.[merijski] of.[icir]" Vikert na svečanoj sjednici Srpske dobrotvorne zadruge dao novčani prilog od $100 \mathrm{kr}$. zemunskom srpskom Crvenom krstu. ${ }^{41}$ Bez obzira na to što se radilo o humanitarnom događaju, teško da su njegovi nadređeni na to mogli gledati s odobravanjem. Stoga ne čudi da je upravo Vikert zajedno sa zemunskim gradskim senatorom Đorđem Koturom dočekao srpsku vojsku te s njim predao grad majoru Svetozaru Đukiću. ${ }^{42}$ Promjenjiva ratna sreća, međutim, već tri dana poslije dovela je do toga da su i kratkotrajni osloboditelji i oni koji su ih kao takve dočekali bili prisiljeni napustiti grad i prebjeći u Srbiju. S budućom suprugom i punicom Monarhiju je napustio i Vikert, a doskora je bio primljen u redove protivničke vojske u činu natporučnika. ${ }^{43}$ Nije trebao dugo čekati ni na promjenu državljanstva. U novinama je već početkom listopada objavljeno da je primljen „u podanstvo” druge države. ${ }^{44}$

\footnotetext{
37 O tome više u: HORVAT, Pobuna omladine.

38 HORVAT, Živjeti u Hrvatskoj 1900 - 1941., 47-48.

39 HR-HDA-79-UOZV-SDDS, 2417/1916. (Dopisnica Sofiji Vikert), kut. 5757.

40 HR-HDA-79-UOZV-SDDS, 2254/1915. (uloženo u 900/1916.), kut. 5698 i 4223/1916., kut. 5714.

${ }^{41}$ „Iz našega Zemuna”, Straža (Beograd), 2. 9. 1914., 2.

42 „Na današnji dan pre 15 godina ušla je srpska vojska prvi put u Zemun”, Vreme (Beograd), 10. 9. 1929., 4.

43 HR-HDA-79-UOZV-SDDS, 2254/1915. (uloženo u 900/1916.), kut. 5698 i 4223/1916., kut. 5714.

${ }^{44}$ „Primljeni u podanstvo”, Pravda (Beograd), 4. 10. 1914., 2. Vidi i: „Naši novi podanici”, Straža, 5. 10. 1914., 2.
} 
Veliki se dio zemunskih prebjega nakon okupacije Srbije morao vratiti kućama u grad i njegovu okolicu. Nove (stare) vlasti dočekale su ih kao sumnjivce, neke od njih i osuđenike za veleizdaju. ${ }^{45}$ Postupak zbog „sumnje zločina veleizdaje" vođen je i protiv izvjesnoga zemunskog trgovca Koste Mikšića, koji je sredinom siječnja 1916. u iskazu danom zemunskom redarstvu nakon povratka iz Srbije među ostalim izjavio da se Vikert nakon napuštanja Monarhije „vjerio” s Mirjanom Nikolić te da se po prodoru austrougarske i bugarske vojske u Srbiju i povlačenju srpskih snaga sa zaručnicom i njezinom majkom nalazio u Kosovskoj Mitrovici, planirajući bijeg u Italiju preko Crne Gore. $^{46}$

To mu je najvjerojatnije i uspjelo jer se sredinom 1916. nalazio u Ženevi u Švicarskoj, ${ }^{47}$ družeći se s drugim srpskim izbjeglicama poput Milana Pribićevića. ${ }^{48}$ Tamo mu, svemu usprkos, očito nije bilo sjajno jer je, čini se, propitivao mogućnosti povratka u Monarhiju. To se, prema dostupnim podacima, nije dogodilo budući da mu je kao vojnom bjeguncu i veleizdajniku prijetilo uhićenje, a vjerojatno i teško kažnjavanje. Uostalom, na samu informaciju o Vikertovu mogućem povratku hitno je reagirala Središnja defenzivno doglasna služba, pa i sam šef glavnoga stožera Kraljevskoga vojnog zapovjedništva u Zagrebu potpukovnik Heinrich v. Droffa naredivši premetačinu stana njegove sestre Sofije, „komptoiristice”49 u zagrebačkoj Kukovićevoj ulici 28, ${ }^{50}$ radi potrage za korespondencijom, odnosno dokazima o održavanju kontakata s traženom osobom. No tom je prilikom izuzeta samo jedna dopisnica iz svibnja 1914. te Vikertova fotografija u časničkoj odori iz 1909., slikana u ateljeu glasovitoga ljubljanskog fotografa Ludvika Kreme, ${ }^{51}$ vjerojatno brata ili bliskoga rođaka njegove majke Ivane. ${ }^{52}$ Da su se redarstvo i obavještajna služba ozbiljno pripremali za Vikertovo uhićenje govori i to da je fotografija umnožena osamnaest puta te da je njezinih šesnaest kopija proslijeđeno Središnjoj defenzivno doglasnoj službi na daljnje uredovanje. ${ }^{53}$

45 Usp. HR-HDA-79-UOZV-SDDS, 2254/1915. (izvorna oznaka zapisnika 281 s), kut. 5698.

46 HR-HDA-79-UOZV-SDDS, 2254/1915., kut. 5698.

47 O prebacivanju zemunskih Srba nakon okupacije Kraljevine Srbije u Ženevu preko Crne Gore i Italije više vidi u: HR-HDA-79-UOZV-SDDS, 1509/1916., kut. 5698.

48 Milan Pribićević (1877. - 1937.). Austrougarski i jugoslavenski časnik i političar te brat poznatijih Svetozara i Adama. Rođen u Brodu na Savi, školovao se u vojnoj školi u Grazu te postao časnik austrougarske vojske. Godine 1904. prešao u vojnu službu Kraljevine Srbije, 1907. napisao Revolucionarni statut prevratničke organizacije „Slovenski jug”, a 1918. predvodio izaslanstvo srpske vojske koje je na poziv Narodnoga vijeća posjetilo Zagreb. Kao član Samostalne demokratske stranke, sudjelovao u političkom životu Kraljevstva SHS do 1923. („Pribićević, Milan”).

49 Vjerojatno računovotkinje.

50 Danas Hebrangova ulica.

51 HR-HDA-79-UOZV-SDDS, 2417/1916., kut. 5709.

52 Da su Vikertovi mogli imati rodbine u Sloveniji, posredno svjedoči i činjenica da je Vikertova sestra Sofija sredinom 1914. živjela u Celju, privređujući kao zaposlenica veletrgovine tamošnjega poznatog poduzetnika Rudolfa Stermeckog (HR-HDA-79-UOZV-SDDS, 2417/1916. /Dopisnica Sofiji Vikert/, kut. 5757).

53 HR-HDA-79-UOZV-SDDS, 2417/1916., kut. 5709. 
S druge strane, malo je razloga za sumnju u Vikertovu odanost srpskoj vojsci kao i činjenicu da joj je pristupio posve dragovoljno. O tome osim spomenutih izravnih navoda svjedoče i njegova kasnija višestruka odlikovanja. Pored „Medalje za vojničke vrline” bio je nositeljem „Medalje za oslobođenje i ujedinjenje” te "Albanske spomenice”. ${ }^{4}$ "Medalja za vojničke vrline” od 1883. dodjeljivala se redovnim ili pričuvnim vojnicima za „osvedočene usluge Kralju i otadžbini”, odnosno „vanredno odličnu i revnosnu službu u vreme mirno, vanredno ili ratno uopšte”. ${ }^{55}$ "Medalja za oslobođenje i ujedinjenje” utemeljena je 1920. i dodjeljivana veteranima Velikoga rata, sudionicima u borbama protiv Centralnih sila 1914. - 1918. kao spomen na te događaje te oslobođenje Srbije i ujedinjenje s ostalim narodima u Kraljevstvu Srba, Hrvata i Slovenaca. ${ }^{56}$ I „Albanska spomenica” utemeljena je 1920., kao sjećanje na povlačenje srpske vojske kroz Albaniju. Na njezinu aversu oko Aleksandrova profila pisalo je „Svojim ratnim drugovima Aleksandar”, a na drugoj strani medalje stajala je kratka rečenica „Za vernost otadžbini”. Naravno, dodjeljivala se isključivo pripadnicima srpske vojske koji su proživjeli i preživjeli uzmak pred austrougarskim i bugarskim snagama u zimu 1915./16. godine. ${ }^{57}$

Uostalom, i sam je Vikert nekoliko godina nakon rata kao predsjednik „organizacije dobrovoljaca u Zemunu”, pozdravljajući generala Voju Živanovića, prilikom posvete zastave te udruge podsjetio na borbe zemunskih dobrovoljaca na Solunskom bojištu upravo pod zapovjedništvom spomenutoga visokoga srpskog oficira. ${ }^{58}$ Malo je vjerojatno da bi bio na čelu dobrovoljačke organizacije i govorio o borbama zemunskih dobrovoljaca u srpskoj vojsci da se i osobno nije istaknuo u rečenim događajima. O tome su, napokon, svjedočili i sljedeći događaji.

\section{Stare zasluge za novu službu}

Što god da je Vikerta ponukalo na pridruživanje srpskoj strani na samom početku, moralo mu je donijeti višestruke koristi nakon završetka Velikoga rata. Stoga ne treba posebno čuditi njegovo daljnje napredovanje u administrativnom i policijskom aparatu starojugoslavenske države. Rijetko se tko iz prečanskih krajeva mogao pohvaliti njegovim životopisom. Nažalost, nije poznato koliko je vremena proveo u inozemstvu i kada se ponovno vratio na ratište, odnosno u staru (novu) domovinu. Ono što znamo jest da je unatoč spomenutim ratnim zaslugama iz pobliže nepoznatih razloga početkom proljeća 1920. napustio aktivnu vojnu službu u činu pričuvnoga žandarmerijskog potpukovnika. Sam je, komentirajući te događaje, naveo da je od 20. ožujka 1920. do 30. listopada 1923. „bio u ostavci i za to se vrijeme bavio vlastitom

54 HR-HDA-223-MUP NDH, inv. br. 1768.

55 CAR, MUHVIĆ, Odlikovanja Srbije i Jugoslavije, 405-408.

56 „Spomenica rata za oslobođenje i ujedinjenje 1914-1918. godine”.

57 CAR, MUHVIĆ, Odlikovanja Srbije i Jugoslavije, 444-450.

58 „Osvećenje dobrovoljačke zastave”, Vreme, 9. 6. 1924., 4. 
ekonomijom". ${ }^{59}$ Budući da mu je supruga bila posjednica zemunskoga paromlina i dioničarka Srpske banke, ${ }^{60}$ sredstava za pristojan život vjerojatno $\mathrm{mu}$ nije nedostajalo.

Stare mu zasluge međutim nisu posve zaboravljene. Posljednjih dana listopada 1923. imenovan je za „sekretara I. kl[ase]” u Ministarstvu unutarnjih poslova, a doskora je, kako je spomenuto, upisao i beogradski Pravni fakultet, na kojem je i „diplomirao” 1927. Iste je godine na temelju toga preveden u viši činovnički razred ${ }^{61}$ položivši „državni stručni ispit za upravno polic. struku” pri ministarstvu u kojem je bio namješten. ${ }^{62}$ Kada je napokon zapuhao, povoljan vjetar u leđa Vikert je svakako znao iskoristiti. U službi se snašao više nego dobro. Već u siječnju 1929. postavljen je za šefa „otseka za žandarmeriju” Ministarstva unutarnjih poslova, a u kolovozu te godine imenovan je i policijskim savjetnikom istoga državnog tijela. Nešto kasnije, 27. ožujka 1930., kraljevim ukazom namješten je za „upravnika policije u Banja luci”, ${ }^{63}$ a koliki je zaista bio njegov utjecaj u tamošnjem društvenom životu govori činjenica da ga je u tom razdoblju tisak u nekoliko navrata spominjao i kao „upravnika grada", ${ }^{64}$ što ne treba čuditi jer su ovlasti tadašnjih policijskih šefova bile široke i relativno nedefinirane. ${ }^{65}$ Krajem studenoga 1932. iz Banje Luke je u svojstvu savjetnika ponovno bio povučen na službu u nadležno beogradsko ministarstvo. ${ }^{66} \mathrm{U}$ lipnju 1933. unaprijeđen je u policijskoga inspektora Ministarstva unutarnjih poslova, u kolovozu sljedeće godine nalazimo ga na mjestu „šefa otseka javne bezbednosti” iste državne institucije, ${ }^{67}$ a 26 . srpnja 1935. imenovan je „[u]pravnikom policije u Sarajevu”. Nije naodmet spomenuti i da je u službi redovito ocjenjivan najvišim ocjenama kao „marljiv, vredan i pouzdan činovnik” te da je u prosincu 1928. odlikovan Ordenom Sv. Save V. reda. ${ }^{68}$

59 HR-HDA-223-MUP NDH, inv. br. 1768.

60 Usp. Srpska banka.

${ }^{61}$ HR-HDA-223-MUP NDH, inv. br. 1768. Usp. i: „Zloglasni Rikard Vikert”, Hrvatski narod, 22. 4. 1941., 8.

62 HR-HDA-223-MUP NDH, inv. br. 1768.

63 HR-HDA-223-MUP NDH, inv. br. 1768; „Slava žandarmerije u Beogradu”, Vreme, 26. 6. 1929., 5. Usp. i: „Banja Luka je dočekala rođendan Nj. V. kralja...”, Vreme, 18. 12. 1931., 4.

64 „Gradske vijesti (Slava u vojnoj bolnici)”, Nova štampa (Banja Luka), 15. 11. 1930., 2; „Otvorena izložba stručne škole u Banjoj Luci”, Pravda, 25. 6. 1932., 14.

${ }_{65}$ GRGIĆ, Između režimske ideologije i potreba građana, 586-587.

66 „Gradske vijesti (Srdačan ispraćaj g. Vikerta)”, Banjalučke novosti (Banja Luka), 3. 12. 1932., 2; „Svoje drage prijatelje i poznanike u Banjoj Luci”, Banjalučke novosti, 3. 12. 1932., 1.

67 „Ispiti u Domaćičkoj školi Udruženja domaćica i matera”, Pravda, 13. 12. 1934., 7. Iste godine Vikerta kao inspektora Ministarstva unutarnjih poslova nalazimo i u svojstvu ispitivača u Centralnoj policijskoj školi u Zemunu („Ispiti u Centralnoj policijskoj školi u Zemunu”, Pravda, 19. 8. 1934., 18; „Osnivanje radio-emisionih policiskih stanica u celoj zemlji”, Vreme, 24. 10. 1934., 5).

68 HR-HDA-223-MUP NDH, inv. br. 1768; „Odlikovanja na dan 1. decembra”, Vreme, 3. 12. 1928., 4. 


\section{Zaštitnik sirotinje}

Vikertov dolazak u Banju Luku krajem ožujka 1930. morao je biti povezan $s$ tadašnjim društvenim i političkim stanjem u zemlji. Ukidanje ustava, promjena unutarnjega uređenja zemlje, zabrana rada političkih stranaka i društava te stroga cenzura tiska očito su za provođenje u djelo tražili čovjeka Vikertovih karakternih zasada. Uostalom, na njegovu je dolasku inzistirao ban Vrbaske banovine Svetislav Tisa Milosavljević osobno, navodeći da je „upravnik policije u sedištu banovine ujedno i referent bana za policijske stvari opšteg značaja” te da na to mjesto mora biti postavljena osoba $s$ „punim kvalifikacijama i lice koje poznaje rad i organizaciju policije i potpuno je upućen u celokupnu službu javne bezbednosti, a sem toga da je u moralnom i nacionalnom pogledu ispravno i pouzdano". Budući da Banja Luka kao sjedište uprave Vrbaske banovine od 1929. nije, usprkos odredbama Zakona o unutrašnjoj upravi, imala čovjeka na čelu uprave policije, ban je od Upravnoga odelenja Ministarstva unutarnjih poslova zatražio što žurnije popunjavanje toga mjesta, predlažući za nj Vikerta riječima „jer ga lično poznam i imam uverenje da će u svakom pogledu odgovoriti potrebama toga položaja". ${ }^{69}$

Ne čudi stoga da je kao „upravnik policije” Vikert postao istaknutom ličnošću u onodobnom društvenom životu prisustvujući svim važnijim događajima koji su se u to vrijeme odvijali u središnjem gradu Bosanske krajine, počevši od posjeta ministra prosvjete Bože Maksimovića ${ }^{70}$ te predsjednika Vlade Petra Živkovića potkraj srpnja 1930., ${ }^{71}$ preko predaje novih zastava pukovima jugoslavenske vojske u rujnu 1930. ${ }^{72}$ svečane akademije u čast Zrinskoga i Frankopana u banjalučkom Hrvatskom domu, ${ }^{73}$ proslave spomendana vojvode Petra Mrkonjića (Petra I. Karađorđevića) ${ }^{74}$ obilježavanja Dana ujedinjenja ${ }^{75}$ te proslave kraljeva rođendana ${ }^{76}$ tijekom 1931., pa sve do skupštine Odbora za podizanje doma kralja Petra I. sredinom ožujka 1932. godine. ${ }^{77} \mathrm{U}$ društvenom je životu bila aktivna i Vikertova supruga Mirjana, osobito se ističući na javnim događajima koji su nosili srpska nacionalna obilježja. ${ }^{78}$

\footnotetext{
69 HR-HDA-223-MUP NDH, inv. br. 1768.

70 „Ministar prosvjete g. Boža Maksimović u Banjoj Luci”, Nova štampa, 19. 7. 1930., 1.

${ }^{71}$ „Svečani doček Predsjednika vlade generala Petra Živkovića”, Nova štampa, 23. 7. 1930. 1 .

72 „Svečana predaja novih zastava pukovima jugoslavenske vojske. Ukaz i riječ nj. v. Kralja”, Nova štampa, 7. 9. 1930., 1; „Jutros je Banja Luka oduševljeno dočekala novu pukovsku zastavu. Impozantna manifestacija ljubavi prema Kralju, vojsci i Otadžbini”, Nova štampa, 10. 9. 1930., 1.

73 „Svečana akademija u spomen Zrinskog i Frankopana”, Nova štampa, 5. 5. 1931., 1.

74 „Proslava dana Vojvode Petra Mrkonjića”, Nova štampa, 17. 6. 1931., 1.

75 „Banja Luka je na svečan način proslavila Dan Ujedinjenja”, Nova štampa, 3. 12. 1931., 1.

76 „U Banjoj Luci je svečano proslavljen Kraljev rođendan”, Nova štampa, 19. 12. 1931., 1.

77 „Godišnja skupština Odbora za podizanje doma Kralja Petra”, Nova štampa, 15. 3. 1932., 3.

78 „Proslava dana Vojvode Petra Mrkonjića”, Nova štampa, 17. 6. 1931., 1; „Sveslavensko veče Kola srpskih sestara", Nova štampa, 23. 2. 1932., 1.
} 
Posve je razumljivo da režimu naklonjen tisak nije donosio pregršt podataka o stvarnim razlozima Vikertova dolaska u Banju Luku. Međutim, i iz ono malo dostupnih podataka može se razabrati da namještenje u policiji nije značilo isključivo obračunavanje sa svakodnevnim redarstvenim poslovima poput reguliranja gradskoga prometa, ${ }^{79}$ privođenja sitnih kriminalaca, prosjaka i prostitutki te rješavanja nerijetkih zločina izazvanih prekomjernom konzumacijom alkohola. ${ }^{80}$ Jasno je da je na čelo policije Vikert postavljen da zaštiti vlastodršce, što je, čini se, činio predano. Jedan od rijetkih zabilježenih slučajeva iz kojih se to da uočiti jest podatak da je policija dala kazniti šestoricu građevinskih radnika koji su, najvjerojatnije nezadovoljni radnim uvjetima, poticali kolege na napuštanje posla izgradnje činovničkih stanova u jednom banjalučkom naselju. Zbog incidenta su bili kažnjeni s nekoliko dana zatvora. ${ }^{81}$ U vrijeme Vikertova mandata iz pobliže nepoznatih razloga suđeno je i poznatom banjalučkom odvjetniku i haesesovcu dr. Filipu Čodriću, koji je zbog „krivice iz člana 5 Zakona o zaštiti javne bezbednosti i poretka u državi” u odsutnosti kažnjen sa 4 mjeseca zatvora i 3.000 dinara novčane kazne. ${ }^{82}$

Pored toga, Vikert je nastojao izgraditi tamošnju policiju na suvremenim temeljima. Tako je već krajem rujna 1930. donesena odluka o osnivanju „prijavnog odjeljenja Policijske uprave”, koje je trebalo kontrolirati broj i kretanje tamošnjega stanovništva. Zadatak ureda bilo je i provođenje skorašnjega popisa žitelja, koji je trebao biti potpuniji i precizniji od onoga iz 1921. godine. Čini se da je u tome banjalučka policijska uprava kao središnje redarstveno tijelo imala zahtjevan zadatak budući da su se od protekloga popisa dogodile znatne promjene u obliku velikoga prirasta stanovništva, a trebalo je razriješiti i nemale poteškoće pri registraciji žitelja i mjesta njihova stanovanja poput imenovanja ulica i dodjeljivanja kućnih brojeva. Zanimljivo je da su odlukom banske uprave za poslove popisivanja stanovništva upravitelju policije na raspolaganje bili stavljeni svi učitelji tamošnjih osnovnih škola. ${ }^{83}$ Popis je doista doskora proveden (od 1. listopada do 20. studenog 1930.), a prema njemu je Banja Luka u to vrijeme imala ukupno 25378 stanovnika, od toga 10 014 pravoslavaca, 7418 muslimana i 7208 katolika. Istovremeno je s popisom u potpunosti ustrojeno „Prijavno odjelenje Uprave policije na najmodernijoj osnovi”, u kojem su se preko sustava kartoteka mogli pratiti podaci o stalnom i privremenom stanovništvu, osobama u „namešteničkom odnosu”, sudskim

79 „Gradske vijesti (Bicikli dobivaju brojeve)”, Nova štampa, 12. 6. 1931., 3; „Naredba”, Banjalučke novosti, 4. 6. 1932., 6.

80 Usp. npr. „Gradske vijesti (Naredba Uprave policije za Duhovski vašar)”, Nova štampa, 24. 5. 1931., 3; „Gradske vijesti (Najezda cigana i džepara u Banja Luku)”, Nova štampa, 30. 5. 1931., 3; „Gradske vijesti (Kažnjen zbog bogohuljenja)”, Nova štampa, 24. 7. 1931., 3; „Naredba", Banjalučke novosti, 11. 6. 1932., 5.

${ }^{81}$ „Gradske vijesti (Kažnjeni podstrekači na štrajk)”, Nova štampa, 21. 9. 1930., 2.

82 "Gradske vijesti (Dr. Filip Čondrić kažnjen sa 4 mjeseca zatvora i 3.000 dinara globe)”, Nova štampa, 25. 12. 1930., 2.

83 „Gradske vijesti (Popis stanovništva Banja Luke i osnivanje prijavnog odjeljenja Policijske Uprave)", Nova štampa, 30. 9. 1930., 2. 
i/ili policijskim kažnjenicima, traženim osobama, kao i onima kojima je grad poslužio samo kao prolazno boravište. Prilikom popisa, koji je zbog nepismenosti i podložnosti žitelja „konzervativnim predrasudama” proveden uz znatne poteškoće, u Banjoj Luci je što registrirano, što imenovano ukupno 125 ulica, a predgrađa su imala 14 ulica i naselja. ${ }^{84}$

Još je po nečemu Vikert ostao zapamćen za vrijeme upravljanja banjalučkom policijom. Priljev velikoga broja stanovnika iz ruralne okolice, suša i nerodne godine doveli su do potrebe osnivanja gradske ubožnice poradi zbrinjavanja znatnoga broja „sirotinje i nezaposlenih radnika”. „Uboški dom” otvoren je na kraljev rođendan 17. prosinca 1931. inicijativom tadašnjega bana Vrbaske banovine Milosavljevića, ali pod izravnom skrbi i ravnanjem uprave policije. Budući da je ubožnica bila zamišljena kao „provizorna ustanova” i da nije imala nikakve veze sa sredstvima državnoga budžeta, morala se oslanjati isključivo na dragovoljne priloge imućnih građana Banje Luke i okolice. ${ }^{85} \mathrm{Vi}$ kert je, čini se, u prikupljanju sredstava odigrao najvažniju ulogu. Iako je trebala biti otvorena samo u zimskim mjesecima, ubožnica je nastavila s radom i na proljeće, pa je u sto dana njezina djelovanja podijeljeno 25000 obroka, a tijekom toga razdoblja u prostorima prenamijenjene stare općinske zgrade oko 10000 osoba pronašlo je „ogrijev i konačište”. Ukupni trošak cjelokupne akcije iznosio je oko 2,40 dinara po osobi, ${ }^{86}$ uključujući osim rečenoga ogrjeva i smještaja hranu te higijenske potrepštine „(sapun, kupanje, šišanje i brijanje po jednom nedeljno)" ${ }^{87}$ Vikert je u tome, sudeći po objavama u tisku, bio iznimno aktivan. Možda ponešto uveličano, ali ne i bez temelja, tadašnji su novinski prilozi tvrdili:

„Naša policija svojim humanim radom oko zbrinjavanja sirotinje i poduzi-
manja mjera za dobro građana, zaista prednjači, te se može smatrati pravom
stražom, policijom i socijalnom ustanovom. Zato, s puno povjerenja, građan-
stvo susreće njenoga upravnika skromnog i marljivog g Vikerta koji bez ikak-
ve buke i reklame zadužuje svakodnevno sve građane, a naročito sirotinju." ${ }^{8}$

Da navedeno nije bilo slučajnost i da je upravitelj policije za vrijeme boravka u njihovu gradu zaista uspio zadobiti naklonost velikoga broja Banjalučana svjedoči i pamtljivi ispraćaj nakon što je po službenoj dužnosti ponovno vraćen u beogradsko Ministarstvo unutarnjih poslova. Na „srdačan i spontan ispraćaj, kakav nije doživeo ni jedan činovnik ni pre ni posle rata”, održan u nedjelju 27. studenog 1932., pristiglo je, prema pisanju tiska, „ogromno mnoštvo sveta” da bi Vikertu osobno zahvalilo za uspjehe na „humanom i kultur-

\footnotetext{
84 „Banja Luka ima 25.378 stanovnika”, Nova štampa, 26. 11. 1930., 2.

85 „Rad Uboškog doma u brojevima”, Nova štampa, 4. 3. 1932., 3. Usp. i: „Inspekcija g. bana Milosavljevića u Uboškom Domu”, Nova štampa, 25. 2. 1932., 1.

${ }^{86} \mathrm{Za}$ usporedbu, jedan broj Nove štampe u kojoj su objavljeni ovi podaci u to je vrijeme stajao 1 dinar.

87 „Rad Uboškog doma u brojevima”, Nova štampa, 4. 3. 1932., 3.

88 „Gradske vijesti (Novi vatrogasni red)”, Nova štampa, 27. 2. 1932., 3.
} 
nom polju”. Kolike su bile njegove humanitarne zasluge svjedoči to da ga su najugroženiji stanovnici gradske periferije prozvali „otac sirotinje”. ${ }^{89}$

U povodu Vikertova odlaska njegovi su „prijatelji i poštovaoci” u hotelu „Bosna” priredili banket kojem je pribivalo 200 osoba. Na svečanom događaju predstavnici banjalučkoga teniskoga kluba, čiji je Vikert bio predsjednik, slavljeniku su darovali „vrlo lepu ukusno izrađenu statutu tenis-igrača”, a od ostalih građana predana mu je „u zlatnom povezu 'Spomenica' sa nekoliko hiljada potpisa ljudi iz svih [...] društvenih krugova” ${ }^{90}$ Da je i upravitelj policije bio dirnut ponašanjem svojih tada već bivših sugrađana, svjedoči i njegova zahvala objavljena u tamošnjim dnevnim novinama:

„Sve moje drage prijatelje i poznanike u Banjoj Luci koji me prigodom moga premeštenja duboko dirnuše mnogim dokazima iskrenog prijateljstva molim, da i ovim putem izvole primiti izraz moje trajne zahvalnosti. Rihard Vikert. Savetnik Ministarstva un. poslova sa suprugom." ${ }^{11}$

Na zlu glasu

Vikertov karakter imao je i naličje, znatno drukčije od upravo opisanoga. Njegovo navodno okrutno ponašanje prema političkim protivnicima režima 30-ih i početkom 40-ih godina, odnosno njegovu „zloglasnost” za koju ga je prozivao endehazijski tisak, zasad je doduše moguće samo neizravno potvrditi. Arhivska vrela o tome uglavnom šute, a novinarske tvrdnje tiskane na početku državne tvorevine nastale na zgarištima omražene starojugoslavenske zajednice nije uputno uzimati nedvojbenima bez obzira na to koliko se naoko mogu učiniti točnima. A one su, kao i nekoliko pribilježenih sjećanja suvremenika te Vikertova kasnija sudbina, nažalost i jedine (posredne) informacije kojima raspolažemo o njegovu policijskom djelovanju i upravljanju, napose sarajevskim redarstvom.

Teško da se Vikert svojevremeno nije jako zamjerio dijelu društva čiji su pripadnici u travnju 1941. isplivali kao nedodirljivi gospodari situacije u Hrvatskoj. Nedugo nakon proglašenja NDH tisak je za nj tvrdio da se na mjestu upravitelja sarajevske policije 1935. - 1940. nalazio u vrijeme „najkrvavijeg protuhrvatskog režima”, proganjajući Hrvate „u Sarajevu kroz cijelo vrijeme [...] službovanja sve do dolaska u Zagreb za ravnatelja redarstva”. Prema istim navodima, Vikert u policijskim postupcima „nije prezao od nikakovih sredstava”, nemilosrdno kažnjavajući hrvatsko stanovništvo za isticanje nacionalnih obilježja i sprovodeći „hrvatske omladince i djake kao razbojnike okovane u lance [...] kroz cijeli grad" da bi naposljetku bili upućeni prema beogradskom Sudu za zaštitu države. Navodno je zbog sličnoga razloga 1938.

\footnotetext{
89 „Gradske vijesti (Srdačan ispraćaj g. Vikerta)”, Banjalučke novosti, 3. 12. 1932., 2.

90 Isto.

91 „Sve moje drage prijatelje i poznanike u Banjoj Luci...”, Banjalučke novosti, 25. 12. 1932., 1.
} 
dao kazniti i policijskoga nadstražara Ivana Saka kad je „salutirao po vojnički sviranje hrvatske himne" ${ }^{92}$ Taj je policijski dužnosnik doista u to vrijeme službovao u Sarajevu, a u listopadu 1939. „po potrebi službe” premješten je u zagrebačko redarstvo. Pravim imenom Ivan Sack, u vrijeme premještaja u Zagreb nalazio se na dužnosti policijskoga stražara prve klase. ${ }^{93}$ Ako je tisak i pogriješio u sitnicama, najvjerojatnije je informacija o Vikertovu postupanju prema njemu barem djelomice istinita.

Vikert je bio jedan od najzaslužnijih i za razbijanje sarajevske organizacije Komunističke partije tijekom 1936., kada su gotovo svi tamošnji viđeniji komunisti bili uhićeni, procesuirani i osuđeni na duže zatvorske kazne, i kada je zbog režimske represije među članstvom zavladao strah i nepovjerenje prema daljnjem organiziranom političkom djelovanju. Nedugo nakon toga sarajevska je policija „začuđujućom brzinom” rasturila i rad studentskih udruženja preko kojih je dio mlađega partijskog članstva pokušao nastaviti s političkim radom. ${ }^{94}$ Osobita se brutalnost, čini se, pokazivala prema toj mlađoj populaciji, o čemu svjedoče događaji s početka prosinca 1936., kada je nakon prosvjeda u sarajevskoj Srednjoj tehničkoj školi (koji je Vikert nastojao primiriti i osobno pregovarajući s nezadovoljnicima) policija iznimno nasilno i uz pomoć vatrogasaca, šmrkovima i pendrecima, razbila prosvjed učenika te obrazovne ustanove kojem su se pridružili i drugi đaci i studenti. ${ }^{95}$

Slična djelatnost nastavljena je tijekom čitavoga Vikertova upravljanja sarajevskom policijom. Međutim, kako je vrijeme odmicalo, i njemu je postajalo sve jasnije da se stvari za režim ne odvijaju na najbolji način. Zbog toga je tijekom 1939. pokušao dodatno pojačati policijsku „ofenzivu protiv svih organizacija radničke klase, komunista i uopšte svih koji su ispoljavali ma kakav napredan duh” tražeći od nadležnih tijela donošenje novoga „Zakona o suzbijanju komunističkog legalnog i polulegalnog rada”, koji bi imao „jače sankcije” od Zakona o zaštiti države, smatrajući da su se komunisti prestali upuštati u djelatnost koja je dolazila pod njegov udar i okrenuli propagandi unutar školskoga sustava, književnosti i umjetnosti. ${ }^{96}$ Teško je vjerovati da je policijski upravitelj na meti imao samo jedne protivnike onodobnoga beogradskog režima i da su sarajevski hrvatski nacionalisti skloni ustaškom pokretu nesmetano provodili svoje aktivnosti. Posljedično se i spomenute novinske reakcije nakon uspostave NDH o kojima je bilo riječi mogu smatrati barem bliskima istini. Uostalom, nečime je morao zaslužiti dolazak na čelo zagrebačke policije umjesto neodrješitoga Vragovića.

Prelazak na novu dužnost bio je izvjestan već 14. prosinca 1940., kada je Ministarstvo unutarnjih poslova uputilo banu Ivanu Šubašiću dopis u kojem ga je obavijestilo o Vikertovu premještaju iz Drinske u Banovinu Hrvatsku.

92 „Zloglasni Rikard Vikert”, Hrvatski narod, 22. 4. 1941., 8.

93 HR-HDA-890-BH ZP, inv. br. 14.385.

94 DUGONJIĆ, „Okupljanje i borba omladine Sarajeva”, 486-488.

95 BEŠLIĆ, „O štrajku đaka Srednje tehničke škole”, 542-545.

96 DUGONJIĆ, „Okupljanje i borba omladine Sarajeva”, 519. 
Odluka je formalno provedena u djelo „Ukazom Kraljevskih Namjesnika od 21. prosinca 1940 br 35568 Pr na prijedlog Bana banovine Hrvatske", kojim je dotad prvi sarajevski policajac postavljen za banskoga savjetnika III. položajne grupe 1. stupnja „kod Banske Vlasti u Zagrebu”, a odlukom potonjega tijela 28. prosinca 1940. dodijeljen je na službovanje Redarstvenom ravnateljstvu u Zagrebu. Istoga je dana započeo s upravljanjem. Od tada pa sve do 5. travnja 1941. i ukaza Petra II. o postavljanju za ravnatelja Redarstvenoga ravnateljstva provodio je zadatke ravnanja policijom kao vršitelj dužnosti. ${ }^{97}$

Isti tisak koji je nemilice napadao „hrvatoždera” Vikerta za njegov je dolazak u hrvatsku metropolu optuživao drugoga poznatoga režimskog Hrvata - dr. Jurja Šuteja, ${ }^{98}$ prvaka Hrvatske seljačke stranke (HSS), narodnoga poslanika u beogradskom parlamentu i ministra financija u kabinetima Dragiše Cvetkovića i Vladka Mačeka, Dušana Simovića ${ }^{99}$ te tijekom rata u izbjegličkim, londonskim vladama. ${ }^{100}$ Šutej je Vikertove metode poznavao iz Sarajeva, u kojem je imao odvjetničku pisarnicu, a sam je kao umjereni haesesovac $i$, poslije, beogradski ministar bio izravno zainteresiran za opstanak jugoslavenske države. Uostalom, očito je upravo Vikert na njegovo traženje svojevremeno provodio uhićenja političkih neistomišljenika poput onoga kada su sredinom 1939. zbog posjedovanja ,ilegalnih spisa i drugih stvari” privođeni sarajevski srednjoškolci, pristaše „hrvatske desničarske politike”. ${ }^{101}$ Nije stoga začudno da je isti tisak koji je pozorno pratio sarajevske događaje ${ }^{102}$ potkraj 1940. bio dobro upućen i u to tko je i zašto na čelo zagrebačke policije doveo donedavno prvoga sarajevskog policajca. Upravo se on, prema novinskim napisima, prokušanim metodama trebao suprotstaviti izraženim nacionalističkim težnjama pripadnika i simpatizera ustaškoga pokreta, koji je počeo uzimati sve više maha, osobito među sveučilištarcima.

Navodno je Šutej osam dana prije njegova dolaska u Zagreb Vikerta osobno pozvao na razgovor u Beograd, upućujući ga na korake koje mora poduzeti u hrvatskoj prijestolnici. Osim obračuna s ustaškim pokretom, novi je upravitelj navodno imao i zadatak štititi Šutejevu obitelj, koja je prebivala u Zagrebu na adresi Radišina ulica $7{ }^{103}$ posebice sina Zdravka, kojem je na raspolaganje ostavio i ministarski automobil za osobnu upotrebu. Iako je u izvornim vrelima potvrđeno da se Šutejev sin doista zvao Zdravko i da je 40-ih godina XX.

97 HR-HDA-223-MUP NDH, inv. br. 1768.

98 Šutej je rođen u Podorašcu kraj Konjica 4. prosinca 1899. od oca Matije i majke Marije, slovenskih useljenika u Bosnu. Bio je oženjen Savkom (Savom) rođ. Novokmet (HR-HDA1561-SDS RSUP SRH, inv. br. 300.214; HASANBEGOVIĆ, „Iz korespondencije Ademage Mešića uoči uspostave Banovine Hrvatske”, 975, bilj. 8).

99 „Dr. Šutej zaštitnik zloglasnog Vikerta”, Hrvatski narod, 23. 4. 1941., 4; „Šutej, Juraj”.

100 HR-HDA-1561-SDS RSUP SRH, inv. br. 300.214.

101 „Dr. Šutej predao tužbu sudu”, Hrvatski narod, 7. 7. 1939., 1.

102 Usp. „Hrvatska politika u Bosni”, Hrvatski narod, 28. 7. 1939., 6.

103 Danas Ulica Božidara Adžije. 
stoljeća bio student zagrebačkoga Pravnog fakulteta, ${ }^{104}$ nedavno je objavljen novinski prilog u kojem je sarajevski odvjetnik Mladen Šutej, sinovac ministra financija Jurja, odnosno sin njegova brata Zdravka, također sarajevskoga odvjetnika, ponešto zamutio priču navodeći da su Juraj i Sava Šutej imali sina „Zlatana”, također pravnika, koji je 1941. „s kraljem” napustio Jugoslaviju i vratio se iz Londona tek „po sporazumu Tito-Šubašić” ${ }^{105}$ Najvjerojatnije se međutim radi o istoj osobi jer Zlatanu ili bilo kojem drugom potomku Jurja i Save u vrelima nema ni traga. Čini se da je intervjuirani Šutej ili pobrkao imena ili naveo bratićev obiteljski nadimak. Izrečena sudbina Zdravka/Zlatana svakako se uklapa u čitavu priču. Imao je razloga bježati pred novim režimom jer je navodno upravo on kao polaznik Pravnoga fakulteta za vrijeme studentskih prosvjeda u Zagrebu potkraj $1940 .{ }^{106}$ pozvao redarstvo „da provali na sveučilište" i uhiti njegove prohrvatski nastrojene kolege, od kojih je većina poslije osuđena te je do početka rata izdržavala kazne u Lepoglavi i Kruščici kraj Viteza. ${ }^{107}$

Osjećajući se nedodirljivim na poziciji moći koju je tada zauzimao, Zdravkov otac Juraj, čini se, nije skrivao namjere od suvremenika. Tako je u svojem zagrebačkom stanu na Božić 1940., odgovarajući na upit kako je mogao Vikerta dovesti u Zagreb, navodno odgovorio:

„Ja njega trebam u Zagrebu jer je on 'poznati policajac' i u stanju je objesiti i svoga oca za jednu grupu ili orden, ne žacajući se pri tom ni najokrutnijih sredstava. On će dobiti toliko novčanih sredstava, da će mu uspjeti utamaniti ovu plaćeničku frankovačku bagru." 108

I sam je zagrebački nadbiskup Alojzije Stepinac u svojem dnevniku zabilježio Vikertov dolazak na čelo zagrebačke policije. Kao uzrok je navodio posvemašnji nered u društvu i činjenicu da je vlastima zbog gubitka svakoga autoriteta trebao čovjek ,jake ruke”. O Vikertu je i prije njegova dolaska dobio informacije i iz Sarajeva. Katolička spisateljica Štefanija Jurkić obavijestila ga je o razgovoru sa sarajevskim nadbiskupom dr. Ivanom Šarićem, od kojega je saznala da je Vikert tražio njegovu preporuku prije odlaska u hrvatsku metropolu. Sarajevski nadbiskup to međutim nije želio učiniti, pa je umjesto preporuke zagrebačkim katolicima upućeno upozorenje da budu na oprezu jer je supruga novoga upravitelja policije „srpkinja i velika svetosavska”. ${ }^{109}$

104 HR-HDA-1561-SDS RSUP SRH, inv. br. 300.214; HR-HDA-501-PF, Nacional 1940.-1941. Pravnici.

105 „Prvi put ispričana priča: Sarajevo u doba NDH”.

106 Zbog tih je događaja Senat početkom prosinca donio odluku o privremenoj obustavi rada Zagrebačkoga sveučilišta „s motivacijom da se umire duhovi” („Sveučilište ostaje zatvoreno još tri dana”, Jutarnji list, 4. 12. 1940., 14).

107 „Dr. Šutej zaštitnik zloglasnog Vikerta”, Hrvatski narod, 23. 4. 1941., 4. Usp. i iskaz A. Platzera dan OZNA-i sredinom 1945. u: HR-HDA-1561-SDS RSUP SRH, inv. br. 301.255.

108 „Dr. Šutej zaštitnik zloglasnog Vikerta”, Hrvatski narod, 23. 4. 1941., 4.

109 Ovdje bi valjda trebalo stajati „svetosavka” (Ljubo BOBAN, „Dnevnik Alojzija Stepinca. Kaos na sve strane", Danas /Zagreb/ 9 /1990/, br. 442, 67). 
Vrlo brzo po dolasku u Zagreb, 5. siječnja 1940., Vikert je i osobno posjetio Stepinca, očito držeći važnom potporu i naklonost nadbiskupova autoriteta. Stepinac je nakon razgovora zabilježio da ga je Vikert izvijestio da nije mason kako su to prikazivali neki njemački mediji te da se sa suprugom vjenčao u katoličkoj crkvi. Valjda želeći dodatno se ulagivati crkvenim autoritetima, predložio je uvođenje misa i propovijedi za zagrebačke policajce, za što mu je nadbiskup obećao i posebnoga duhovnika. Osim razgovora o tadašnjem vanjskopolitičkom stanju, Stepinac je zamolio Vikerta da pripazi na „komunističke pipke", što je ovaj i obećao, pa se nadbiskupu nakon susreta činilo da novi upravitelj policije nije „takav kakvog se prikazivalo” (ostavljajući doduše vremenu da pokaže pravu istinu). Stepinac je u kontekstu toga sastanka spomenuo i pooštravanje policijskoga djelovanja u Zagrebu, osobito prema „t. z. frankovcima to jest hrvatskim nacionalistima", izražavajući pritom sumnju da će uslijed ukupnoga stanja u okruženju to na kraju biti od veće koristi. ${ }^{110}$

Vikert je, to se ne smije izgubiti iz vida, bio samo provoditelj odluka donošenih na višim razinama vlasti. Veza je, dakako, sezala sve do Beograda, ali su izravni nalogodavci bili mnogo bliže. O tome, osim Šutejeva primjera, svjedoči i snažna povezanost tadašnjega bana Banovine Hrvatske Šubašića s Vikertovim potezima na čelu zagrebačke policije. Bilo da se radilo o naoko banalnim susprezanjima nacionalnih težnji kao u slučaju uvođenja komesarijata u Matici hrvatskoj, kada je Vikert po Šubašićevu nalogu zatražio prekrajanje (objektivnoga) policijskog izvještaja o Matičinoj godišnjoj skupštini održanoj 29. prosinca 1940., što je poslužilo kao povod za uvođenje kontrole nad tim društvom, ${ }^{111}$ ili mnogo opasnijim zadacima poput onoga koji je pred njega zamalo stavljen prilikom ožujskoga prevrata 1941. godine.

Tada je Vikert, barem tako svjedoče kasniji podaci temeljeni na izjavama izravnih sudionika događaja, iskazao nedvosmislenu odanost osobama uz čiji je blagoslov i dospio na čelo zagrebačkoga redarstva. Vladko Maček, vođa HSS-a, stranke koja je formirala vladajuću koaliciju, puč usmjeren prema Cvetkovićevoj i svojoj vladi te regentu knezu Pavlu dočekao je u Zagrebu. O puču ga je u 6 ujutro 27. ožujka 1941. iz Beograda izvijestio ministar financija i stranački kolega Šutej. U kraljevu vlaku na povratku iz Bleda u Beograd puč je dočekao i „knez-namjesnik Pavle”. Usprkos zdvojnosti izazvane beogradskim događajima, Maček je kneza žurno pokušao nagovoriti da se odupru puču i silom uznastoje očuvati postojeću vladu i (prije svega) njezin vanjskopolitički smjer utvrđen nedavnim potpisivanjem sporazuma o nenapadanju s Njemačkom. Vikert, koji je i sam pribivao sastanku na zagrebačkom kolodvoru i kasnije u Banskim dvorima, u tome je trebao odigrati važnu ulogu. Na izravan Mačekov upit s koliko ljudi raspolaže i ima li hrabrosti uhititi zapovjednika 4. armijskoga korpusa, urotnicima sklonoga generala Nedeljkovića, koji im

${ }^{110}$ Ljubo BOBAN, „Dnevnik Alojzija Stepinca. Ususret najcrnjem”, Danas 9 (1990), br. 443, 66.

111 „O postavljanju komesara u Matici hrvatskoj”, Hrvatski narod, 30. 4. 1941., 6; HAMERŠAK, „Komesarijat u Matici hrvatskoj”, 847. 
se mogao suprotstaviti s vojskom, ovaj je odgovorio: „Vi naredite a ja ću izvršiti.” Unatoč Vikertovoj odanosti izravnim zagrebačkim nalogodavcima, od daljnje akcije na kraju nije bilo ništa. ${ }^{12}$ Knez Pavle odlučio je odbiti Mačekov prijedlog prepustivši političke igre još uvijek malodobnom Petru II. te urotnicima i generalima Borivoju Mirkoviću i Dušanu Simoviću. Četiri HSSova bivša ministra naposljetku su ušla u Simovićevu vladu, a Vikert se, kao i njegovi zagrebački mentori, priklonio novom stanju. U tome je još jednom pokazao neupitnu poslušnost kao što je (ako je vjerovati zapisima o događaju prenesenim iz navedene jedinice literature) obećao učiniti i u odsudnim i opasnim trenucima. Možda, na kraju, Šutejeva karakterizacija upravitelja policije navodno izrečena potkraj prosinca 1941. i nije bila daleko od stvarnih obrisa njegove ličnosti. Možda se radilo o prevelikoj ambicioznosti, nekritičnom uvidu u vlastite sposobnosti i mogućnost utjecaja na društvene prilike ili - običnom častohleplju. Kako god bilo, izvjesno je da je Vikert činio sve za onoga kome je trenutačno služio. Možda je i njemu samom, doduše, ponekad bilo teško nedvosmisleno razlučiti tko je to zapravo.

\section{Šoprek i drugovi}

Kao što je jasno da je bio provoditeljem dobivenih naputaka, isto je tako sigurno da ih nije mogao izvršavati sam. U vrijeme kada su neprijatelji režima bili snažniji nego ikada prije, Vikert je pored sebe morao imati osobe sposobne i odlučne u djelo bespogovorno provesti naložene zadatke, bez obzira na postupke prema protivnicima. Ako je vjerovati onodobnom tisku, a postoje naznake da su bar neki od priloga o Vikertu dolazili iz pera njegova dobroga poznavatelja i suradnika iz sarajevskih i zagrebačkih dana Ivana Topalija, ${ }^{113}$ najvažniji „pouzdanici” ravnatelja policije u Zagrebu bili su šef „referade za teroriste" Ladislav Šoprek te detektivi Mladen Bjelac i (Josip Ludvik) Kereškenji. ${ }^{114}$

Ti napisi, bez obzira na očitu nenaklonjenost prema subjektima, čini se, i toga su puta sadržavali jezgru istine. I Šoprek i Bjelac i Kereškenji dokumentirani su izvornim arhivskim vrelima, a njihova sudbina nakon uspostave NDH govori u prilog spomenutim tiskovnim navodima. Najpoznatiji od Vikertovih suradnika, i njegova „desna ruka”, bio je Šoprek, koji je na kraju uspio spasiti glavu pred ustaškim režimom. To previše i ne čudi jer se već u predratno doba prometnuo u jednoga od sposobnijih (protu)obavještajaca u zagrebačkoj policiji s izgrađenom mrežom osobnih i profesionalnih poznanstava. Uostalom, te će sposobnosti samo dodatno biti potvrđene njegovim kasnijim životopisom.

U zagrebačkoj se policiji vodio kao „pomoćni perovođa VII položajne grupe" i kao takav je krajem travnja 1941. otpušten iz državne službe. Od-

112 HOPTNER, Jugoslavija u krizi 1934-1941., 254-256.

113 O tome vidi: HAMERŠAK, „Komesarijat u Matici hrvatskoj”, 847, bilj. 49.

114 „Zloglasni Šoprek pouzdanik ‘bana’ Šubašića”, Hrvatski narod, 24. 4. 1941., 9. 
luka o otkazu nije mu, naravno, nikada uručena jer se već tada nalazio izvan dohvata ustaških vlasti. ${ }^{115}$ Sam se poslije hvalio da su mu ustaše nudili ostanak u policijskom aparatu da bi - sada u njihovo ime - nastavio s progonima komunista, ali je on to navodno odbio. ${ }^{116}$ Usprkos formalnoj poziciji pomoćnoga pisara, Šoprekove su ovlasti i utjecaj u policiji, čini se, bili mnogo veći. U tisku i izvorima spominje se da je u Zagrebu studirao i apsolvirao pravo, ali da obrazovanje nikada nije uspio privesti kraju. Zanimljivo je da je u to doba bio i član zbora zagrebačke Opere. Neko je vrijeme službovao u rodnom Sarajevu, ${ }^{117}$ a u pobliže nepoznatom trenutku bio je postavljen za „pisara pripravnika Uprave grada Beograda”. S tog je mjesta i u istom statusu krajem studenoga 1934. premješten u zagrebačku policiju. Budući da je u Zagreb stigao „po molbi” i žurno (pritom je brzojavno urgirao čak i ministar unutarnjih poslova Živojin Lazić), ${ }^{118}$ ne bi čudilo da je njegov dolazak u Zagreb osobno zahtijevao upravitelj policije Stanoje Mihaldžić. Šoprek je tada dodijeljen političkom odsjeku redarstva, zaduženom za obračunavanje s proturežimskim neistomišljenicima, koje je zajedno s Brankom Zwergerom i Ljubomirom Beloševićem - poznatim policijskim agentima i atentatorima na povjesničara i političara Milana Šufflaya ${ }^{119}$ - „na krvoločan način zlostavljao”. ${ }^{120}$

Po uspostavi Banovine Hrvatske nakratko je premješten u Novi Sad, ali se na vlastiti zahtjev i uz Mihaldžićevu pomoć ponovno vratio u Zagreb kao „nenadoknadivi policijski stručnjak”. Navodno je osobnim Šubašićevim zalaganjem bio dodijeljen zagrebačkom redarstvenom ravnateljstvu iako je i dalje formalno bio namješten u Novom Sadu, ubirući pored redovne plaće i nemale iznose dnevnica. Čini se da mu je jedan od zadataka bila i briga o banovoj osobnoj sigurnosti. Kada je potkraj 1940. na čelo zagrebačke policije došao Vikert, Šoprek je sasvim prebačen k zagrebačkom redarstvu, ${ }^{121} \mathrm{u}$ kojem je vodio „tako zvanu referadu za teroriste” te je uz upravitelja bio „svemoćan”, zbog čega su ga se „pošteni redarstvenici” bojali. U to je vrijeme umjesto Zwergera i Beloševića dva nova pomagača pronašao u Bjelcu i Kereškenjiju. ${ }^{122}$

Čini se da čitavo vrijeme službovanja Šoprek nikako nije mogao izići na kraj s vlastitim primanjima. Zbog toga se za poprilično visoke svote zaduživao u Sarajevu, Beogradu, Novom Sadu i Zagrebu. Prilikom premještaja u zagrebačko redarstveno ravnateljstvo početkom 1941. na njegovoj je plaći „sjedilo”

115 HR-HDA-223-MUP NDH, inv. br. 14.986

116 HR-HDA-1561-SDS RSUP SRH, inv. br. 312.796.

117 Usp. HR-HDA-1561-SDS RSUP SRH, inv. br. 312.796; „Zloglasni Šoprek pouzdanik 'bana' Šubašića”, Hrvatski narod, 24. 4. 1941., 9.

118 HR-HDA-890-BH ZP, inv. br. 14.135.

119 Usp. STIPANČEVIĆ, „Mlada Jugoslavija - teroristička ispostava zagrebačke policije”, 145-146.

120 „Zloglasni Šoprek pouzdanik ‘bana’ Šubašića”, Hrvatski narod, 24. 4. 1941., 9.

121 Rješenje o namještenju za pomoćnoga perovođu Redarstvenoga ravnateljstva u Zagrebu nosi nadnevak 30. siječnja 1941., a Šoprek je na dužnost nastupio 7. veljače iste godine (HRHDA-890-BH ZP, inv. br. 14.135).

122 „Zloglasni Šoprek pouzdanik ‘bana’ Šubašića”, Hrvatski narod, 24. 4. 1941., 9. 
čak deset ovrha - što bankovnih i kreditnih ustanova, što privatnih osoba. ${ }^{123}$ Život na visokoj nozi imao je cijenu. Šoprek ju je plaćao tuđim novcem. Ne treba posebno naglašavati da su svi njegovi dugovi u travnju 1941. otišli u vjetar.

Krajem 30-ih postao je simbolom svireposti i policijske brutalnosti. Zasigurno ne bez temelja, „prijatelji političkih uhapšenika” u letku pod naslovom Protiv mučenja u zagrebačkoj Glavnjači! naveli su da su policijska zvjerstva nad Markom Oreškovićem, Đurom Špoljarićem i drugim radnicima na sušačkoj policiji, ${ }^{124}$ kada su rečeni dulje od mjesec dana i na najbestijalnije načine premlaćivani do iznemoglosti, počinjena „od istih onih Šopreka i drugih policijskih bandita, koji su i prije tzv. 'Sporazuma' ${ }^{125}$ mučili radnike i hrvatske borce". U istom su propagandnom tekstu autori, najvjerojatnije zagrebački komunisti, pozvali hrvatski narod da digne glas protiv policijskoga terora navodeći da javnost mora biti upoznata s tim „da u Zagrebu muči i mrcvari hrvatske radnike i radnice - hrvatožder i bandit Šoprek, koji vrši svoj krvnički posao po nalogu Šubašića i Mačeka!"126

S prljavom je rabotom, dakako, započeo znatno prije. Vjerojatno odmah po dolasku u zagrebačku policiju, kada je u ophođenju s političkim zatočenicima samo nastavljena svirepa tradicija iz vremena po zlu upamćena Janka Bedekovića. ${ }^{127}$ Tako su primjerice Šoprek i njegovi pomagači 1936. užarenim glačalom po golome tijelu mučili građevinskoga radnika Đuru Halabarca, koji je tijekom komunističkih demonstracija u siječnju te godine usmrtio jednoga redarstvenog stražara te dvojicu ranio, zbog čega je poslije osuđen na smrt vješanjem. ${ }^{128}$ Da na zlu glasu nije bio bez razloga, tvrdilo se i znatno poslije. Već kada se u emigraciji prometnuo u vrsnoga profesionalnog obavještajca, o njemu je Vekoslav Bučar ${ }^{129}$ izjavio: „Znam dobro Šopreka! zabijao je čavle pod nokte žrtvama zagrebačke policije, u eri zloglasnog Bedekovića [...]." ${ }^{30}$ Iako autor navoda vjerojatno griješi povezujući Šopreka s Bedekovićem, metode njegova djelovanja očito su mu bile jako dobro poznate.

\footnotetext{
123 HR-HDA-890-BH ZP, inv. br. 14.135.

124 Orešković i Špoljarić boravili su u policijskom zatvoru u Sušaku u veljači i ožujku 1940. godine.

125 Cvetković-Maček.

126 OČAK, „Građa za biografiju Marka Oreškovića Krntije”, 37-38.

127 O tome više u: STIPANČEVIĆ, „Vampir iz Petrinjske. Obrisi portreta Janka Bedekovića”, 121-126; STIPANČEVIĆ, „Mlada Jugoslavija - teroristička ispostava zagrebačke policije”, 131 .

128 „Zloglasni Šoprek pouzdanik 'bana' Šubašića”, Hrvatski narod, 24. 4. 1941., 9; SENTIĆ, LENGEL-KRIZMAN, Revolucionarni Zagreb 1918-1945, 67-68.

129 Vjerojatno slovenski publicist i putopisac, autor knjige Politička istorija slovenačka (Beograd: Politika, 1939).

130 HR-HDA-1561-SDS RSUP SRH, inv. br. 312.796. Zasad nema potvrde da je Šoprek doista bio u zagrebačkoj policiji u vrijeme Bedekovićeva upravljanja. Najvjerojatnije se radi o Bučarevoj omašci, što ne treba čuditi jer je Šoprek u zagrebačku policiju stigao nedugo nakon što je Mihaldžić preuzeo ravnanje od Bedekovića.
} 
Spomenuti su slučajevi, ako je suditi po tadašnjoj klimi posvemašnje protukomunističke i protuustaške histerije vladajućih krugova, samo djelić onoga za što je Šoprek bio odgovoran. S niskom njegovih sadističkih bisera nisu bili upoznati samo oni koji su nekom nesrećom dospjeli u Petrinjsku 18 nego i šira zagrebačka i hrvatska javnost. Kao što je to tvrdio i ustaški tisak, Šoprek nije okrutno postupao samo s komunistima nego i s „uhićenim hrvatskim nacionalistima”. ${ }^{131}$ Drugim riječima, sa svakim tko se protiv režima usudio podići glavu. Popis njegovih nedjela zasigurno nije kratak.

I ostatak njegova života vrijedan je filmskoga scenarija. Pred ustaškim je režimom pobjegao zajedno s neposredno nadređenim Vikertom, ${ }^{132}$ ali su im se putovi ubrzo razdvojili. Pokazat će se da je Šoprek bio pametniji i(li) s(p) retniji. Bježao je prema Italiji i naposljetku spasio glavu. Podaci koji govore o tom razdoblju njegova života poprilično su zamućeni. Spominje se da je jedno vrijeme nakon bijega iz Zagreba boravio u Ljubljani, a zatim i u njemačkom, a poslije i talijanskom logoru. Što god da je istina, uspio se izvući rabeći svoje redarstveno-obavještajne sposobnosti. Koristio se mnogim lažnim imenima. Bio je poznat kao „Bradica”, „Vladimir”, „Vladimir Babič”, „Carlo Palluci (Peruzzi, Peruggi)”, „Luigi Scisciani”, „Cristina Moriconi”, „Vlada Kojadinović” i „Tatar”. Za trajanja rata radio je za interese vlade u izbjeglištvu, surađujući pritom s američkom, engleskom, francuskom, njemačkom i grčkom obavještajnom službom. Smatralo ga se i glavnim obavještajcem Vladka Mačeka za Italiju. Imao je razgranatu mrežu suradnika i mnogo novca kojim ih je plaćao. Bio je oženjen Talijankom, s kojom je imao kćer. Prvu je suprugu ostavio u Novom Sadu. Smatran je za inteligentnu i beskrupuloznu osobu te velikoga materijalista i ženskara. Jugoslavenska ga je obavještajna služba držala pod prismotrom od kraja Drugoga svjetskog rata, a posebice nakon sredine 50 -ih godina, kada se tješnje povezao s njemačkom obavještajnom službom počevši ponovno uspostavljati kontakte s predratnim suradnicima te prikupljati obavještajne podatke o jugoslavenskom režimu. ${ }^{133}$ Zbog toga je Služba državne bezbjednosti sredinom 1975. pod kodnim nazivom "Tiper” planirala njegovu otmicu i ilegalno prebacivanje u Jugoslaviju. ${ }^{134}$ Nakon neprovođenja te akcije „Tatar” je 1976. odlukom Okružnoga suda u Rijeci u odsutnosti osuđen na 15 godina strogoga zatvora. Svemu usprkos, nastavio je s djelovanjem cijelo vrijeme prebivajući u Rimu, uglavnom pod nadzorom jugoslavenskih obavještajaca. Sve do 1990., kada je u siječnju preminuo. ${ }^{135}$ Možda je povremeno čak i radio za jugoslavenske obavještajne službe. S obzirom na navedeno, ne bi bilo posve iznenađujuće.

\footnotetext{
131 „Zloglasni Šoprek pouzdanik ‘bana' Šubašića”, Hrvatski narod, 24. 4. 1941., 9.

132 „Uhićen zloglasni Rikard Vikert”, Hrvatski narod, 2. 5. 1941., 5.

133 HR-HDA-1561-SDS RSUP SRH, inv. br. 312.796.

134 HR-HDA-1561-SDS RSUP SRH, šifra 2, 202.2/81 - 21/1.

135 HR-HDA-1561-SDS RSUP SRH, inv. br. 312.796.
} 
Što se drugih Vikertovih bliskih suradnika iz zagrebačke policije tiče, o njima je sačuvano nemjerljivo manje podataka. To međutim ne znači da je sudbina barem nekih potpuno nepoznata. Redarstveni agent Mladen Bjelac rođen je 1904. u Starome Majdanu blizu Sanskoga Mosta u obitelji državnoga činovnika Stojana i Zore rođ. Lušić. ${ }^{136}$ U zagrebačkoj je policiji djelovao još od kraja 20-ih ili početka 30-ih godina, započevši redarstvenu karijeru kao „stražar pripravnik”, a 1931. promaknut je u policijskoga agenta. Osim u Zagrebu, tijekom nekoliko mjeseci 1934. službovao je u Komesarijatu pogranične policije u Kotoribi. Tamo se međutim „iskazao” nesavjesnim obavljanjem dužnosti kontrole putnih isprava, pa je disciplinski kažnjen obustavom dijela plaće i gubitkom prava napredovanja na dvije godine. Zbog toga je najvjerojatnije doskora i vraćen na službu u zagrebačku policiju. Krajem siječnja 1941. premješten je na dužnost k Pograničnom komesarijatu u Sušaku. ${ }^{137}$ Ondje je najvjerojatnije i dočekao prevrat. Već 14. travnja 1941. uhićen je po nalogu Glavnoga ustaškog stožera. Koliko je novim vlastima bio na zubu govori podatak da je već 4. lipnja „interniran” u pobliže nepoznat koncentracijski logor $^{138} \mathrm{u}$ kojem je poslije najvjerojatnije i skončao.

Kereškenji je, za razliku od Bjelca, uspio umaći ustaškim vlastima. Iako je $\mathrm{u}$ tisku navedeno samo njegovo prezime, ${ }^{139}$ vrlo se vjerojatno radilo o Josipu Ludviku Kereškenjiju. On je kao Bedekovićev kadar na osobni zahtjev primljen u zagrebačku policiju kao policijski stražar - pripravnik u travnju 1934. godine. Rođen je 1906. u Bjelovaru, u zagrebačkoj I. realnoj gimnaziji dogurao je do kraja prvoga razreda, a potom radio kao krojački pomoćnik i „pripravnik finansijske kontrole". Vojnu je obvezu služio kao pitomac zagrebačke pješadijske podoficirske škole (1923. - 1924.) te pri komandi Savske divizijske oblasti (1924. - 1927.). Stručnu školu za policijske izvršne službenike završio je u Zemunu položivši potkraj 1932. propisani državni ispit. U redarstvenoga agenta promaknut je u rujnu 1940. godine. ${ }^{140}$

O njemu je nakon rata i privođenja od komunističkih vlasti pred istražnim organima Odjeljenja zaštite naroda (OZNA) kazivao Juraj Špiler, od 1924. do 1935. zaposlenik zagrebačke policije i šef saobraćajnoga, putovničkoga te odsjeka javne sigurnosti. Špiler je tada za („Ljudevita”) Kereškenjija naveo da je tijekom 1942. dospio u Banat, gdje je postavljen za „nadstražara policijskih agenata kod Komande javne bezbjednosti u Bečkereku”. ${ }^{141} \mathrm{O}$ tome je davao podatke iz prve ruke budući da se osobno nalazio u službi njemačkih okupacijskih vlasti na čelu komande toga grada sve do listopada 1944., kada je pobjegao pred napredovanjem sovjetskih postrojbi. Njegov negdanji nadređeni o Kereškenjiju je izjavio i da je za vrijeme boravka u Bečkereku promijenio

${ }^{136}$ HR-HDA-259-ROZ, inv. br. 388.

${ }_{137}$ HR-HDA-890-BH ZP, inv. br. 11.291.

${ }^{138}$ HR-HDA-259-ROZ, inv. br. 388.

139 „Zloglasni Šoprek pouzdanik ‘bana’ Šubašića”, Hrvatski narod, 24. 4. 1941., 9.

${ }^{140}$ HR-HDA-890-BH ZP, inv. br. 20.897.

${ }^{141}$ Danas Zrenjanin. 
prezime u Wolf te da je prilikom „oslobođenja emigrirao [...] i stupio u službu Gestapoa [...] u Ptuju ili Celju”. O Kereškenjijevoj (Wolfovoj) poslijeratnoj sudbini Špiler nije imao nikakvih saznanja. ${ }^{142}$

Kao Vikertovi suradnici koji su s njim napustili Zagreb poimenično su spomenuti i Ivan (Ivo) Antičević te izvjesni Lazarić. ${ }^{143}$ Iza potonjega se imena krije Milko Lazarić, Istrijan iz Buja rođen 1908., „svršeni pravnik” zagrebačkoga Pravnog fakulteta, „političko-upravni pripravnik” sreza Trnavskoga (Čačak), Račanskoga (Bajina Bašta) i Užičkoga (1933. - 1936.), policijski pristav uprave policije u Sarajevu i pristav Sarajevskoga sreza (1936. - 1939.), zamjenik predstojnika i predstojnik gradske policije Slavonskoga Broda (1938. - 1939.), pristav sreskih načelništava u Slunju, Korenici, Gospiću, Čakovcu (1939. - 1940.) te Đurđevcu (1940. - 1941.). Vrlo je vjerojatno da je Lazarić bio specijaliziran za redarstvene poslove i da je u najvećem dijelu spomenutih mjesta bio namještan upravo zbog obavljanja takvih dužnosti. Zasluge tijekom policijske službe u Sarajevu najvjerojatnije su ga krajem siječnja 1941. dovele u zagrebačko redarstvo. ${ }^{144}$ Njegov negdašnji šef Vikert očito ga je smatrao kadrom potrebnim za provođenje zadataka koje je u bremenitim vremenima preuzeo kao prvi zagrebački policajac.

Za razliku od Vikerta, Lazarić je također 1941. izvukao živu glavu. Kao i Šoprek, nakon sloma Jugoslavije nastojao se dokopati teritorija pod talijanskom kontrolom. U tome je i uspio jer je 1942. na otoku Krku djelovao kao učitelj gimnazije, „četnik”, talijanski doušnik i prokazivač tamošnjih neprijatelja režima. ${ }^{145}$ U Italiju je prebjegao vjerojatno nakon kapitulacije. Tijekom 1945. jugoslavenski su ga obavještajni krugovi spominjali kao Šoprekova bliskoga suradnika koji je iz Barija stigao u Rim da bi izvještavao o tamošnjoj suradnji četnika i savezničkih trupa. Vjerojatno se tada nalazio u Šoprekovoj službi i na njegovu platnom popisu. Navodno se u to vrijeme bavio i novinarskim poslom, što je očito bio paravan za obavještajnu djelatnost. U jednom se izvještaju čak spominjao kao „poručnik, član četničke misije u Bariju” koji sa Šoprekom i drugim jugoslavenskim emigrantima planira utemeljiti obavještajnu grupu koja bi iz sjeverne Italije radila u Jugoslaviji za račun saveznika. Taj je izvještaj navodio da se Lazarić tada hvalio posjedovanjem dokumenata o Šubašićevu djelovanju uoči izbijanja rata. Napadajući ga, izjavljivao je da je u travnju 1941. bio spreman pregovarati s Nijemcima nakon što je već odradio pregovore s ustaškim predstavnicima. Za taj su „izdajnički pokušaj” znali i Šoprek, Antičević i drugi tadašnji zaposlenici zagrebačke policije. Navodno je ban tek na njihovu intervenciju odlučio napustiti Zagreb, iako je spomenute policijske službenike preko Vikerta već bio obavijestio da će osobno dočekati Nijemce. ${ }^{146}$

142 HR-HDA-1561-SDS RSUP SRH, 010.3.7.

143 „Uhićen zloglasni Rikard Vikert”, Hrvatski narod, 2. 5. 1941., 5.

144 HR-HDA-890-BH ZP, inv. br. 16.948.

145 FRANOLIĆ, „Ratni zločini na otoku Krku”, 77.

146 Spomenuto se donekle razlikuje od navoda bivšega šefa Odsjeka za državnu sigurnost Banovine Hrvatske, odnosno voditelja Političkoga referata pri Kabinetu bana Alberta Platzera danih OZNA-i 1945., u kojima je tvrdio da Šubašić s nekolicinom suradnika nije planirao 
Lazarić je, prema izvještaju, o tim događajima iznosio brojne pojedinosti koje je planirao objaviti u memoarima. ${ }^{147}$ To nažalost, čini se, nikada nije učinio iako je imao sklonosti pisanoj riječi. Još za vrijeme boravka u Sarajevu objavio je knjižicu zvučnoga naziva Kako ću preživjeti budući rat? Uputa o načinu odbrane od otrovnih gasova (Sarajevo: Sarajevska štamparija Marko B. Slijepčević, 1936), tri godine poslije Prava i dužnosti općina (Slavonski Brod: Tiskara Vilim Buk, 1939), a u emigraciji, kao vrstan poznavatelj talijanskoga jezika, ${ }_{148}$ Italijansku gramatiku s konverzacijom za samouke (Roma: Giovanni Bardi, 1946). U neko je doba napustio Italiju i preselio se u Sjedinjene Američke Države. Preminuo je 1999. u Las Vegasu. ${ }^{149}$

Ivo Antičević također nije nasumično izabran za premještaj u zagrebačko redarstvo tijekom Vikertova upravljanja. Iako podataka o njegovoj prethodnoj službi nema mnogo, i ono što je dostupno potvrđuje da je, kao i u slučaju prethodno spomenutih policijskih službenika, bio „specijaliziran” za borbu s proturežimskim elementima. Poznato je naime da je u krajem 30-ih bio predstojnik redarstva u Dubrovniku i da ga je u to doba tamošnji profesor Blažo Lopičić sudski optužio zbog sumnjičenja za komunističku djelatnost. Epilog optužbe nije poznat jer je Antičević uskoro upućen za predstojnika redarstva Komesarijata pograničnog, željezničkog i parobrodarskog redarstva u Sušaku. ${ }^{150} \mathrm{U}$ vrijeme njegova upravljanja sušačka je policija postala poznata po brutalnom ophođenju s političkim zatvorenicima, kako je već spomenuto u Oreškovićevu i Špoljarićevu primjeru. Možda je i zbog toga u srpnju 1940. premješten na dužnost predstojnika gradske policije u Vinkovcima, gdje se zadržao do kraja siječnja 1941., kada je premješten na službu k Redarstvenom ravnateljstvu u Zagrebu u svojstvu „redarstvenoga povjerenika”. ${ }^{151}$ Njegova je sudbina nakon napuštanja hrvatske prijestolnice zasad nepoznata.

\section{Posljednje stranice}

Samo nekoliko dana nakon što je pristigao zakašnjeli kraljev ukaz kojim je imenovan za (pravoga) ravnatelja zagrebačkoga redarstvenog ravnateljstva Vikert je bio prisiljen pobjeći iz Zagreba. Nijemci su sa saveznicima u munjevitom i brzo isplaniranom napadu pregazili ostatke kraljevske jugoslavenske vojske, kojoj su Hrvati otkazali poslušnost. ${ }^{152}$ Nestalo je i države i političkih

\footnotetext{
napuštanje države, nego povlačenje „prema jugu”, odakle je trebalo nastaviti „upravljati Hrvatskom”. Doduše, navodio je dalje Platzer, ban se bavio mišlju da uopće ne napušta Zagreb, a to je - po njegovu mišljenju - na kraju učinio više iz straha od moguće ustaške kazne nego zbog drugih razloga (HR-HDA-1561-SDS RSUP SRH, inv. br. 301.255).

147 HR-HDA-1561-SDS RSUP SRH, inv. br. 312.796.

${ }_{148}$ HR-HDA-890-BH ZP, inv. br. 16.948.

149 "Milko Lazaric (1908-1999)”.

${ }^{150}$ HR-HDA-890-BH ZP, inv. br. 16.343.

151 Isto.

152 Usp. OBHOĐAŠ, Vojne operacije u istočnoj Bosni. Zima 1941./1942., 15-20.
} 
elita kojima je ravnatelj policije služio. Zbog prošlosti i postupaka dobro je znao da dolazak novih vlastodržaca ne smije čekati. U tome, vidjeli smo, nije bio jedini.

O njegovu bijegu, koji se najvjerojatnije zbio 10. travnja 1941. u poslijepodnevnim satima, ${ }^{153}$ svoju vladu izvijestio je i njemački generalni konzul u Zagrebu Alfred Freundt brzojavom poslanim toga dana, navodeći da je Maček odstupio, ban Šubašić, podban Ivković154 i „šef policije Wickert” pobjegli te da je na čelo redarstva imenovan bivši policijski upravitelj Vragović. ${ }^{155}$ Potonji je pak nalog za vođenje poslova zagrebačke policije u Vikertovoj odsutnosti dobio od samoga Šubašića, koji se očito zajedno s tadašnjim policijskim ravnateljem i najužim suradnicima već dan prije spremao za napuštanje Zagreba. S druge je strane također jasno da je ban dobro znao koga treba imenovati na čelo redarstva i tko je spreman preuzeti tu dužnost. ${ }^{156}$

Vragović je po ponovnom dolasku na čelo policije za Vikertom izdao tjeralicu. Slično je za nekoliko dana učinilo i redarstvo u Sarajevu. ${ }^{157}$ Bilo je naime poznato da se nakon napuštanja Zagreba uputio prema tom gradu, ${ }^{158}$ vjerojatno držeći da će u poznatoj sredini imati veće izglede za spas. Na njegovu žalost, ta se procjena pokazala pogrešnom. Tadašnji je tisak izvijestio da je s drugim činovnicima umaknuo u šest službenih automobila koje je neovlašteno uzeo od Redarstvenoga ravnateljstva, ${ }^{159}$ što mu svakako nije pomoglo u zametanju tragova. Taj potez govori i da se radilo o prilično ishitrenom i brzopleto organiziranom bijegu, što ne čudi jer se situacija na društvenoj pozornici u Hrvatskoj mijenjala vrtoglavom brzinom. Koliko je s druge strane ustaškim vlastima bilo stalo do uhićenja bivšega prvog policajca Sarajeva i Zagreba svjedoči i naredba zapovjednika oružanih snaga NDH Slavka Kvaternika izdana po dolasku u bosanskohercegovačku metropolu 29. travnja 1941. da se u roku od 48 sati redarstvu imaju privesti svi srpski generali, oficiri i činovnici koji se kriju na teritoriju Bosne i Hercegovine, odnosno u Sarajevu. U proglasu je na dva mjesta posebno istaknuta osoba „zločinca Rikarda Vikerta”, koji je u tom dokumentu ujedno bio jedini poimence navedeni režimski neprijatelj. ${ }^{160}$

U „Vojskovođinu” se pozivu veleizdajom, gubitkom cjelokupnoga imetka i strijeljanjem prijetilo kućevlasnicima koji su skrivali tražene osobe ili prešućivali saznanja o mjestu njihova boravka, pa ne čudi da je već idućega dana, 30. travnja, Vikert pronađen u kući sarajevskoga „drogeriste” Ibrahima Šahinagića. Ne bi čudilo da ga je, bojeći se za vlastiti život, odao sam kuće-

153 „Bivši ravnatelj redarstva Vikert uzeo je neovlašteno 6 automobila”, Hrvatski narod, 17. 4. 1941., 8.

154 Dr. Svetozar Ivković.

155 KRIZMAN, Ante Pavelić i ustaše, 386, bilj. 28.

156 Usp. STIPANČEVIĆ, „Stranputice Joje Vragovića”, 118.

157 „Uhićen zloglasni Rikard Vikert”, Hrvatski narod, 2. 5. 1941., 5.

158 JELIĆ-BUTIĆ, Hrvatska seljačka stranka, 45.

159 „Bivši ravnatelj redarstva Vikert uzeo je neovlašteno 6 automobila”, Hrvatski narod, 17.

4. 1941., 8 .

160 „Naređenje komandanta celokupnih Oružanih snaga NDH od 29. aprila 1941.”, 20-21. 
vlasnik ili netko iz njegove najbliže okoline. O događaju je "radiogramom” odmah obaviješten ravnatelj zagrebačkoga redarstva Vragović, koji je istoga dana požurio izvijestiti nadležno Ministarstvo unutarnjih poslova, nespretno navodeći da je bivši upravitelj „izvršio [...] samoubijstvo”, ali da je prevezen u bolnicu „i ima izgleda da će ostati živ”. ${ }^{161}$ Sličnu je vijest donio i tisak navodeći da si je Vikert prilikom uhićenja u predgrađu Sarajeva ispalio hitac u grudi, neuspješno pokušavajući samoubojstvo, te da mu je pružena sva moguća liječnička pomoć samo da „ostane na životu kako bi mogao hrvatskom narodu odgovarati za svoje zlodjelo". ${ }^{162}$

Vikert im to, podlegavši samoozljeđivanju, ipak nije priuštio. Dokument zagrebačkoga redarstvenog ravnateljstva od 5. svibnja svjedoči da je preminuo istoga dana kada je uhićen - 30. travnja. ${ }^{163}$ Tisak je nakon nekoliko dana donio više pojedinosti o uhićenju i posljedičnim događajima. Tako je navedeno da je Šahinagić u stanu u Pašićevoj ulici unatoč tjeralicama do kraja „brižno čuvao svog prisnog prijatelja" skrivajući ga u tajnoj prostoriji, u kojoj si je Vikert i presudio hicem u sljepoočnicu nakon što su u nju provalili redarstvenici, ${ }^{164}$ neki od njih možda i bivši suradnici negdanjega upravitelja sarajevske policije. Sudbina bivšega austrougarskog dezertera, srbijanskoga dragovoljca iz Velikoga rata, cijenjenoga i omraženoga upravitelja banjalučke, sarajevske i zagrebačke policije u međuratnom razdoblju gotovo da nije mogla imati drugačiji ishod.

\section{Trunci istine}

Ulomci Vikertova života morali su biti rekonstruirani (i) na temelju zapisa koji mu često nisu bili naklonjeni ili su se prema njemu odnosili otvoreno neprijateljski. Prikaz bi zasigurno na kraju drukčije izgledao da su sačuvana drukčija vrela. To je međutim teret s kojim se mora nositi gotovo svaki historiografski prilog. Sudbina posljednjega međuratnog upravitelja zagrebačkoga redarstva rekonstruirana je i predočena u obliku u kojem je do nas uspjela doći. Je li i u kojoj mjeri bliska istini i stvarnim, proživljenim događajima, onkraj je mogućnosti naše današnje spoznaje. Ostaje nadati se da će ju novi nalazi barem dopuniti, ako ne i posve izmijeniti.

Neke su činjenice, dakako, manje prijeporne od drugih. Gotovo i ne moramo sumnjati u podatke o Vikertovu podrijetlu, vojnoj karijeri te napredovanju u činovničko-redarstvenom aparatu starojugoslavenske države. Mnogo je skliskije, pokazalo se, govoriti o nacionalnoj i vjerskoj pripadnosti, privatnom životu, karakteru, pa čak i naobrazbi. Tomu usprkos, na temelju izrečenoga donekle je moguće izgraditi širu sliku jednoga životnog puta koji, uostalom,

161 HR-HDA-223-MUP NDH, inv. br. 1768.

162 „Uhićen zloglasni Rikard Vikert”, Hrvatski narod, 2. 5. 1941., 5.

163 HR-HDA-223-MUP NDH, inv. br. 1768.

164 „Zloglasni Vikert podlegao ozljedama”, Hrvatski narod, 4. 5. 1941., 6. 
možda i nije mogao biti mnogo jednostavniji s obzirom na datosti vremena $\mathrm{u}$ kojem je otpočeo i u kojem je završio.

Vikert je prelaskom na neprijateljsku stranu na samom početku Prvoga svjetskog rata, činilo se, uistinu odigrao pravu kartu. Sumnjivo stečena akademska naobrazba širom je otvorila put k uzdizanju na društvenoj ljestvici. Nemala je stvar postati upraviteljem redarstva triju velikih jugoslavenskih gradova, i to bez opipljivijega obiteljskog pedigrea i utjecajnih političkih veza. Put k uspjesima Vikert si je trasirao isključivo sam. Nažalost, ostalo je nepoznato je li uistinu vjerovao $\mathrm{u}$ ideju integralnoga jugoslavenstva ili je naputke beogradskih centralističkih krugova bespogovorno slijedio po inerciji. Ne bi bio jedini ni u prvom ni u drugom slučaju.

Možda ga je, na kraju, najvjernije prikazao upravo Juraj Šutej, koji ga je dobro poznavao. „Objesiti vlastitoga oca” za napredovanje ili odlikovanje svakako se čini pretjeranošću u karakterizaciji, ali sagledavajući prikupljene podatke, Vikert, čini se, i nije bio ništa drugo do okorjeloga karijerista i bespogovornoga provoditelja naredbi odaslanih iz centara moći. Da mu je bilo dopušteno i da nije stavljen na listu za odstrel ustaških vlasti nakon prevrata 1941., kratkotrajni bi upravitelj zagrebačke policije zacijelo prešao i na njihovu stranu kao što je prije bez poteškoća iskazao odanost Hrvatima - haesesovcima kada su se dokopali važnih položaja. Možda takve osobine moraju biti svojstvene osobama koje se u prijelomnim vremenima nalaze na istaknutim dužnostima. Povijest je prepuna takvih primjera.

$\mathrm{S}$ druge strane, ono što je Vikertu donijelo profesionalno i privatno zadovoljstvo 20 -ih, dovelo ga je do nasilnoga kraja početkom 40 -ih godina. Za „zloglasnost” (pro)oglašavanu u endehazijskim tiskovinama postoje samo posredni dokazi. Izravne se, dakako, i ne može očekivati. Pa i takvi, napabirčeni s različitih strana i od raznih autora, ipak svjedoče o njegovu neprimjerenom ophođenju prema protivnicima jugoslavenskoga režima. O tome, možda više od bilo čega drugog, svjedoči i izbor suradnika koje je prikupio za borbu protiv komunista i ustaša zasjevši na čelo zagrebačke policije. Vikert je, čini se, svojim djelovanjem ipak opravdavao etikete koje su mu lijepljene pored imena.

Kao što to obično biva, njegov je karakter imao i drugu, svjetliju stranu. Onu po kojoj je svojevremeno ostao u sjećanju banjalučkoj sirotinji nastojeći ju spasiti od neimaštine i gladi, ili joj barem ublažiti nevoljnost življenja. Koja je strana na kraju pretezala, ne da se bez ograda prosuđivati. Uostalom, možda to i nije prijeko potrebno jer svatko od nas u sebi istovremeno nosi i raj i pakao. Samo je pitanje u kojem omjeru. Vikert u tome nije bio nikakva iznimka. 


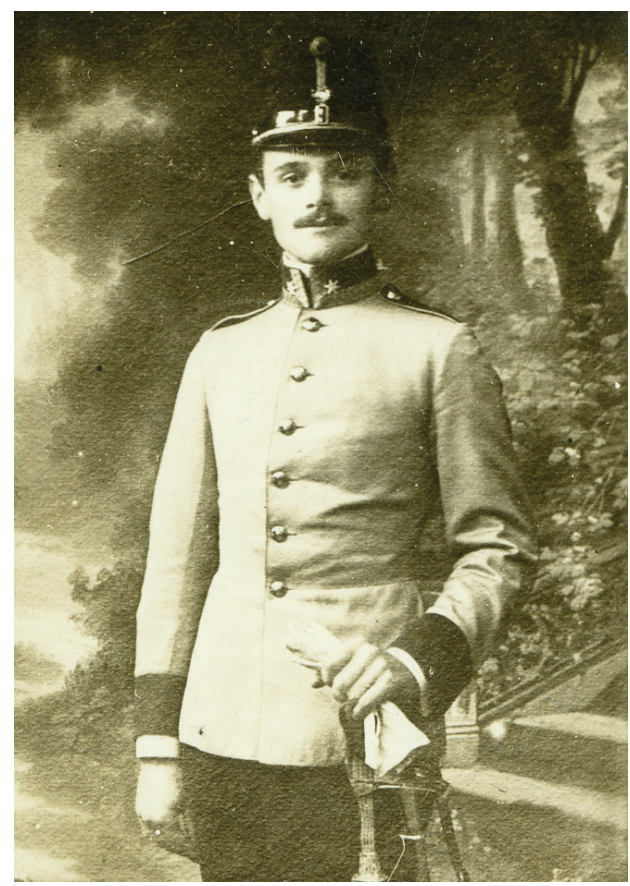

Slika 1. Rikard Vikert u časničkoj odori austrougarske vojske 1909. godine. Kopija fotografije zaplijenjene iz stana njegove sestre Sofije u zagrebačkoj Kukovićevoj ulici 28 (HR-HDA-79-UOZV-SDDS, 2417/1916., kut. 5709).

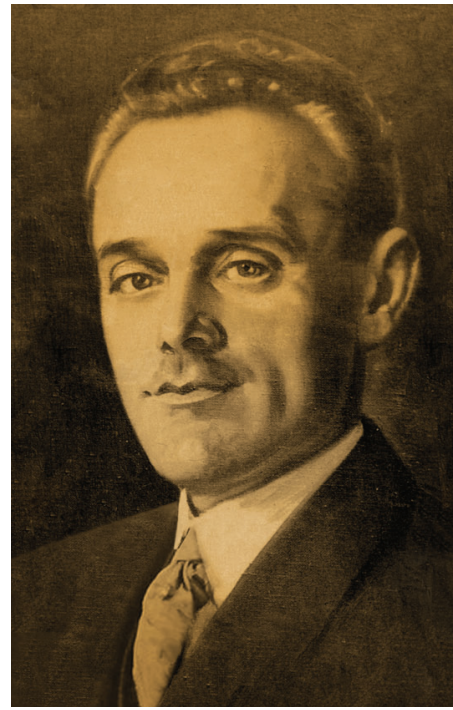

Slika 2. Vikert potkraj policijske karijere (i života). Vjerojatno 1940. (HRHDA-223-MUP NDH, inv. br. 1768).

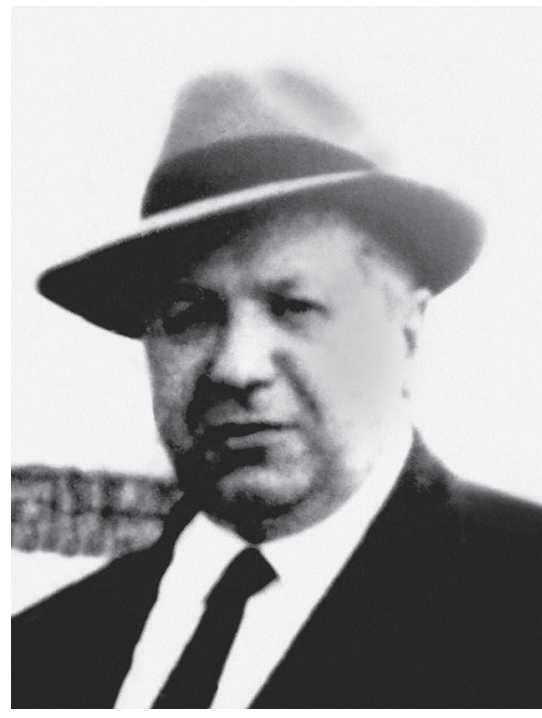

Slika 3. UDBA-ina snimka Ladislava Šopreka iz 1963. (HR-HDA1561-SDS RSUP SRH, inv. br. 312.796) 


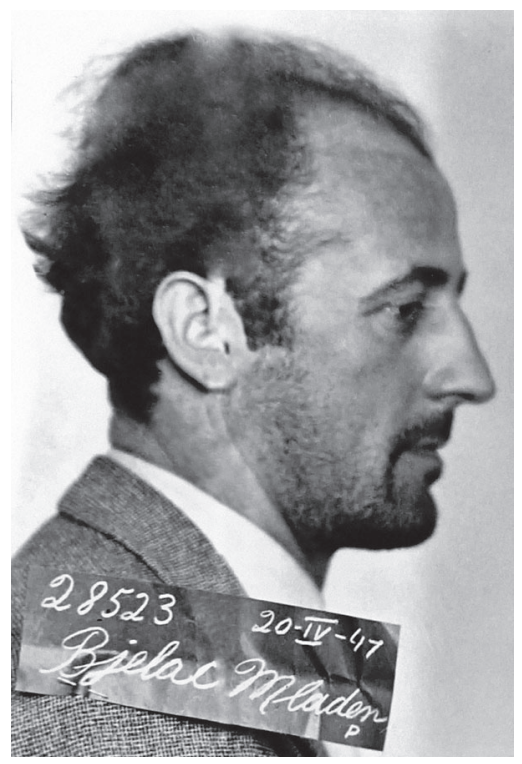

Slika 4. Mladen Bjelac nakon privođenja po ustaškoj policiji (HR-HDA-259-ROZ, inv. br. 388)

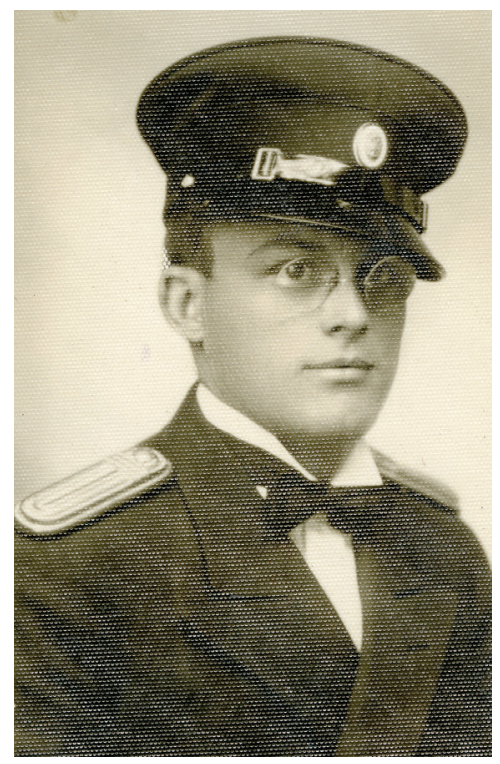

Slika 5. Milko Lazarić na početku redarstvene karijere. Vjerojatno 1934. (HR-HDA-890-BH ZP, inv. br. 16.948). 


\section{Arhivski izvori}

HR-DAVU-VK: Hrvatska, Državni arhiv u Vukovaru, Arhivski sabirni centar u Vinkovcima, Vinkovci:

- fond 124-UOV: Upravna općina Vinkovci.

- fond 38-OŠ JK: Osnovna škola „Josip Kozarac”, Vinkovci.

HR-HDA: Hrvatska, Hrvatski državni arhiv, Zagreb:

- fond 79-UOZV-SDDS: Zemaljska vlada. Odjel za unutarnje poslove. Središnja defenzivno doglasna služba.

- fond 216-MNP NDH: Ministarstvo narodne prosvjete Nezavisne Države Hrvatske.

- fond 223-MUP NDH: Ministarstvo unutarnjih poslova Nezavisne Države Hrvatske.

- fond 259-ROZ: Redarstvena oblast za grad Zagreb.

- fond 501-PF: Pravni fakultet Sveučilišta u Zagrebu.

- fond 890-BH ZP: Personalni spisi državnih službenika Zemaljske vlade, Pokrajinske uprave, oblasnih uprava, Savske banovine, Banovine Hrvatske i ministarstava $\mathrm{NDH}$.

- fond 1448-ZBMK: Zbirka matičnih knjiga i popisa obitelji.

- fond 1561-SDS RSUP SRH: Služba državne sigurnosti Republičkog sekretarijata za unutrašnje poslove Socijalističke Republike Hrvatske.

\section{Mrežni izvori}

„Hrubiány Endre”. Archivum. Pristup ostvaren 17. 6. 2020. https://archivum.asztrik.hu/?q=oldal/hrubiany-endre.

„Milko Lazaric (1908-1999)”. Ancient Faces. Pristup ostvaren 14. 8. 2020. https://www.ancientfaces.com/person/milko-lazaric-birth-1908-death-1999/81976800.

„Norwegian ski manufacturers”. Wikipedia. Pristup ostvaren 28. 10. 2020. https://no.wikipedia.org/wiki/Norske_skiprodusenter.

„Pribićević, Milan”. U: Hrvatska enciklopedija, mrežno izdanje. Leksikografski zavod „Miroslav Krleža”. Pristup ostvaren 25. 5. 2020. https://www. enciklopedija.hr/natuknica.aspx?id=50293.

„Prvi put ispričana priča; Sarajevo u doba NDH: Čuveni sarajevski odvjetnik za 'SB' otkriva sramnu ulogu nadbiskupa Šarića, zločine Maksa Luburića, život u vrijeme ustaša”. Slobodna Bosna, 16. 5. 2020. Pristup ostvaren 3. 8. 2020. https://www.slobodna-bosna.ba/vijest/155224/prvi_put_isprichana_zivotna_pricha_sarajevo_u_doba_ndh_chuveni_sarajevski_odvjetnik_ za_sb_otkriva_sramnu_ulogu_nadbiskupa_sarica_zlochine_maksa_luburica_zivot_u_vrijeme_ustasa.html.

„Rolf Wiborg Thune” (1). Ættesoga. Pristup ostvaren 28. 10. 2020. https:// www.soge.kviteseid.no/individual.php?pid=I44570\&ged=Kviteseid.GED. 
„Rolf Wiborg Thune” (2). Worth Point. Pristup ostvaren 28. 10. 2020. https://www.worthpoint.com/inventory/search?query=rolf+wiborg+thune\&category $=$.

„Spomenica rata za oslobođenje i ujedinjenje 1914-1918. godine”. Wikipedia. Pristup ostvaren 8. 4. 2020. https://sh.wikipedia.org/wiki/Spomenica rata_za_oslobođenje_i_ujedinjenje_1914-1918._godine.

Srpska banka. Pristup ostvaren 25. 5. 2020. http://www.srpska-banka. com/fotografije.htm.

„Šutej, Juraj”. U: Hrvatska enciklopedija, mrežno izdanje. Leksikografski zavod „Miroslav Krleža”. Pristup ostvaren 14. 7. 2020. https://www.enciklopedija.hr/natuknica.aspx?id=60052.

\section{Tisak}

Banjalučke novosti (Banja Luka), 1932.

Danas (Zagreb), 1990.

Hrvatski narod (Zagreb), 1939, 1941.

Jutarnji list (Zagreb), 1913, 1940.

Nova štampa (Banja Luka), 1930-1932.

Pravda (Beograd), 1914, 1932, 1934.

Straža (Beograd), 1914.

Vreme (Beograd), 1924, 1928-1929, 1931, 1934.

\section{Literatura}

BEŠLIĆ, Mumin. „O štrajku đaka Srednje tehničke škole”. U: Sarajevo u revoluciji. Revolucionarni radnički pokret 1937-1941. Sarajevo: Istorijski arhiv Sarajevo, 1976, 541-547.

CAR, Pavel; MUHVIĆ, Tomislav. Odlikovanja Srbije i Jugoslavije. Od 1859. do 1941. Beč: Verlag Militaria, 2009.

DUGONJIĆ, Rato. „Okupljanje i borba omladine Sarajeva na platformi KPJ protiv reakcije i fašizma”. U: Sarajevo u revoluciji. Revolucionarni radnički pokret 1937-1941. Sarajevo: Istorijski arhiv Sarajevo, 1976, 483-540.

FRANOLIĆ, Eugen. „Ratni zločini na otoku Krku”. Diplomski rad, Sveučilište u Rijeci, 2016.

GRGIĆ, Stipica. Između režimske ideologije i potreba građana: Savska banovina 1929-1939. Zagreb: Sveučilište u Zagrebu, Fakultet hrvatskih studija, 2020.

HAMERŠAK, Filip. „Komesarijat u Matici hrvatskoj: od juridičkoga spora do političkoga pravorijeka". Časopis za suvremenu povijest 35 (2003), br. 3: 835-858.

HASANBEGOVIĆ, Zlatko. „Iz korespondencije Ademage Mešića uoči uspostave Banovine Hrvatske. Pismo Društva bosansko-hercegovačkih Hrvata 
u Zagrebu reis-ul-ulemi Fehimu Spahi i vrhbosanskom nadbiskupu Ivanu Šariću iz svibnja 1939." Časopis za suvremenu povijest 40 (2008), br. 3: 969-998.

HOPTNER, Jakob B. Jugoslavija u krizi 1934-1941. Rijeka: Otokar Keršovani, 1972.

HORVAT, Josip. Pobuna omladine. Zagreb: SKD Prosvjeta; Gordogan, 2006.

HORVAT, Josip. Živjeti u Hrvatskoj 1900 - 1941. Zapisci iz nepovrata. Zagreb: Sveučilišna naklada Liber, 1984.

JAJČEVIĆ, Zdenko. 100 godina skijanja u Zagrebu 1894-1994. Zagreb: Zagrebački skijaški savez, 1994.

JELIĆ-BUTIĆ, Fikreta. Hrvatska seljačka stranka. Zagreb: Globus, 1983.

KRIZMAN, Bogdan. Ante Pavelić i ustaše. Zagreb: Globus, 1978.

MIRNIK, Ivan. „Ljetopis Carske i kraljevske pješačke kadetske škole u Karlovcu (1916. - 1917.)". U: Franjo Josip i Hrvati u Prvom svjetskom ratu. Zbornik radova. Zagreb: Matica hrvatska, 2019, 131-174.

„Naređenje komandanta celokupnih Oružanih snaga NDH od 29. aprila 1941. da se u redarstva u roku od 48 sati privedu svi srpski generali, oficiri, činovnici i druge osobe koje se kriju kod pojedinih porodica na teritoriju Bosne i Hercegovine, osobito u Sarajevu”. U: Zločini na jugoslovenskim prostorima u Prvom i Drugom svetskom ratu. Zbornik dokumenata. Beograd: Vojnoistorijski institut, 1993, 20-21.

OBHOĐA ̌́, Amir. Vojne operacije u istočnoj Bosni. Zima 1941./1942. Zagreb: Hrvatski državni arhiv, 2020.

OČAK, Ivan. „Građa za biografiju Marka Oreškovića Krntije”. Arhivski vjesnik 27 (1984): 7-41.

SENTIĆ, Marija; LENGEL-KRIZMAN, Narcisa. Revolucionarni Zagreb 1918-1945. Kronologija. Zagreb: Gradski odbor SUBNOR-a; Institut za historiju radničkog pokreta Hrvatske, 1979.

STIPANČEVIĆ, Mario. „Mlada Jugoslavija - teroristička ispostava zagrebačke policije”. Arhivski vjesnik 62 (2019): 127-155.

STIPANČEVIĆ, Mario. „Stranputice Joje Vragovića. Ulomci biografije jednoga zagrebačkog policajca”. Časopis za suvremenu povijest 52 (2020), br. 1: 101-130.

STIPANČEVIĆ, Mario. „Vampir iz Petrinjske. Obris portreta Janka Bedekovića”. Gordogan (2017), br. 35-36: 104-128. 


\section{SUMMARY}

\section{In the Footsteps of Rikad Vikert, the Last Interwar Chief of the Zagreb Police}

Rikard Vikert (1889-1941) was the last chief of the Zagreb police before the beginning of World War II in this region. He remained at this post only for a short time. Despite this, immediately after the establishment of the Independent State of Croatia, he was declared one of the most wanted persons of the new regime. The reasons for this were related to his earlier policing activities, especially his performance as the head of the Sarajevo police (1935-1940), when he was responsible for the cruel treatment of political dissidents of the old Yugoslav regime.

He was trained to perform police duties as early as the time of the Austro-Hungarian Monarchy, acting as part of the armed forces, i.e. the gendarmerie, immediately after the establishment of the Kingdom of Serbs, Croats and Slovenes. He was well-accepted in centralist circles because he voluntarily left the Austro-Hungarian army and joined the Serbian army at the very beginning of the Great War. In this way, he gained the trust of Belgrade's political elites, which found him suitable for larger police tasks, due to the fact he was an educated officer. From 1923, he was employed by the Ministry of the Interior, and climbed the administrative ladder within the police apparatus. He experienced a professional zenith when he became the chief of the Zagreb police, where he tried to oppose the increasingly strong attempts of members of the Ustasha and communist movements to break the old order. After the entry of German forces into Yugoslavia and the proclamation of the puppet Independent State of Croatia, he and his associates fled Zagreb, trying to find refuge in Sarajevo. There, at the end of April 1941, he committed suicide while resisting an attempt of the Ustasha police to apprehend him.

Key words: Rikard Vikert; biography; police; Kingdom of SHS/Yugoslavia; Independent State of Croatia 